\title{
SCOPE OF THE TREATIES \\ (ARTT. 1, 2 AND 3)
}

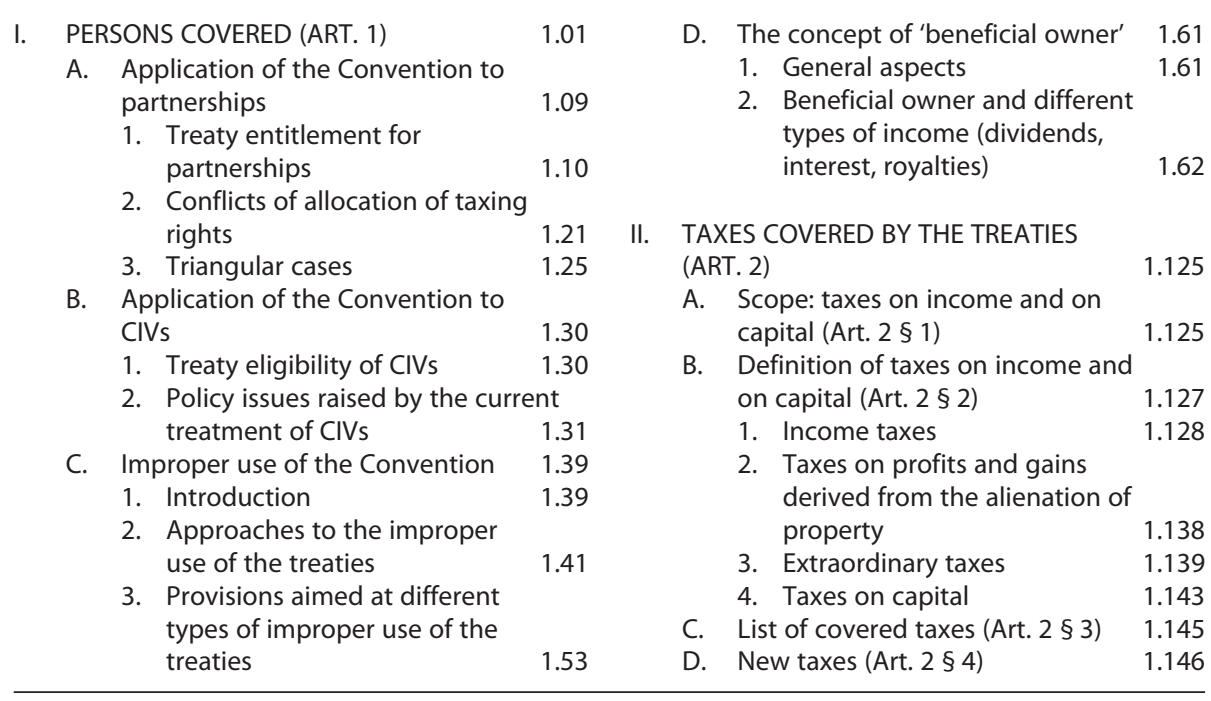

\section{PERSONS COVERED (ART. 1)}

The personal scope of the Convention is defined by the combined application of Artt. 1.01 $1,3 \$ 1$ a) and b), and 4. Art. 1 provides that the Convention shall apply to 'persons' who are 'resident' of one or both of the CSs. The terms 'person' and 'resident' are defined respectively by Art. $3 \S 1 \mathrm{a}$ ) and b) and by Art. 4 \$.

According to Art. $3 \S 1$ a) for the purposes of the Convention, unless the $\mathbf{1 . 0 2}$ context otherwise requires, the term 'person' includes an individual, a company and any other body of persons, while according to Art. $3 \S 1 \mathrm{~b}$ ) the term 'company' means any body corporate or any entity that is treated as a body corporate for tax purposes. According to Art. $3 \S 1 \mathrm{~b}$ ) for the purposes of the Convention, the term 'resident of a CS' means any person (as defined by Art. 3 $\S 1 \mathrm{a})$ ) who, under the laws of the $\mathrm{RC}$, is liable to tax therein by reason of his 
domicile, residence, place of management or any other criterion of a similar nature, and also includes that State and any political subdivisions or local authorities.

1.03 As a result an entity, to be entitled to the Convention, must meet three essential requirements: it must be (i) a 'person' for the purposes of the Convention: (ii) a person 'resident' of one of the CSs; ${ }^{1}$ and (iii) a person resident of one of the CSs which is 'liable to tax' therein. The Commentary observes that treaties are applicable to 'residents' of one or both of the CSs irrespective of nationality. ${ }^{2}$

1.04 The first requirement for an entity, to be entitled to the Convention is that such an entity is a 'person' for the purposes of the Convention. National Courts have addressed this basic issue. For example, a Canadian company had an interest in a European Interest Group (EIG) which carried on an exclusively French business, that for French tax purposes was treated like a partnership. The issue was whether the income received by the Canadian company through the French EIG could be classified under the France-Canada treaty as business profits, dividends, or royalties, but the preliminary issue was whether the EIG was a person for the purposes of the relevant treaty. The Court held that the EIG had a separate legal personality from that of its members and so was a person for the purposes of the treaty. ${ }^{3}$

1.05 Similar issues arose in respect to $S$-corporations in the US. For example, in a German case the issue was whether payments of dividends by a German company to a US S-corporation were subject in Germany to the withholding rate of 5 per cent for substantial shareholdings under the dividends article of the treaty. The Court held that the treaty withholding tax rate did not apply to S-corporations the profits of which were taxed only at the level of their shareholders, so there was no need to mitigate double economic taxation on distributed dividends. ${ }^{4}$

1.06 The requirement that an entity is a 'person' for the purposes of the convention has been specifically addressed in a line of US cases concerning trusts. For example, in the leading case Maximov a trust was recognized as a person for

1 Dual residence is regulated by Art. $4 \S 2$, see infra at paras 2.18-2.52

2 Commentary to Art. $1 \S 1$.

3 France, Conseil d'État (Supreme Administrative Court), 144211, 4 April 1997, Revue de Jurisprudence Fiscale, 1997, 5, 424.

4 Germany, Finanzgericht Nordrhein-Westfalen (Tax Court Nordrhein-Westfalen), 2 K 4034/05, 20 April 2007, Internationales Steuerrecht 2007, 444. 
treaty purposes, but the treaty was not applied because such a trust was not resident of the US. In Maximov the trust was established under the laws of the US State of Connecticut by an individual who was a citizen and resident of the UK. The beneficiaries of the trust were individuals who were citizens and residents of the UK. The trust realized capital gains from US sources and retained these capital gains and added them to the trust corpus rather than distributing them to the UK beneficiaries. The trustees took the position that the capital gains were exempt from tax under the capital gains article of the US-UK treaty to the extent that the gains were retained by the trust for the benefit of individuals who were residents of the UK. The Court noted that such an article of the treaty applied only to persons who were residents of the $\mathrm{UK}$ and held that the trust in this case was clearly a resident of the US and could therefore not rely on that treaty. ${ }^{5}$

A good example of how courts effectively identify an entity as a person for the purposes of the treaty is found in an Australian case, Resource, in which an acquisition structure relied on a chain of partnerships: PR1, a limited partnership formed in the Cayman Islands, bought shares in Co1, an Australian company that conducted activities in Australia and subsequently sold some of its shares in Co1 and realized a gain. PR1 had one general partner (another partnership formed in the Cayman Islands) and several limited partners, most of which were US residents. PR1's affairs were managed by a Delaware LLC. Neither PR1 nor its manager nor any of the partners were resident of Australia. Australia did not have a treaty with the Cayman Islands, but had a treaty with the US (according to which a partnership was a treaty US resident if it was resident of the US for the purposes of its tax, provided that the income was subject to US tax as the income of a resident, either in the hands of the partnership or in the hands of its partners).

The question was which entity actually realized the gains for the purposes of the Australia-US treaty, a question that amounted to the identification of the relevant person for treaty purposes. PR1 submitted that PR1 was a foreign partnership and a flow-through entity under the US domestic laws and that it was not a US tax resident because the residence requirement in the treaty had

5 United States, US Supreme Court, Andre Maximov v. United States, 29 April 1963, 63-1 USTC (CCH) 9438. See also: United States, US District Court for the Southern District of New York, Raymond E. Burdick v. Commissioner, 29 May 1963, 63-2 USTC (CCH) 9527; United States, US Tax Court, Lambert Tree Trust Estate v. Commissioner, 25 June 1962, 38 T.C. 392 (1962); United States, US District Court for the Northern District of California, American Trust Company v. James G. Smyth, Collector of Internal Revenue and United States of America, 6 April 1956, 56-2 USTC (CCH) 9683, reversed 57-2 USTC (CCH) 9824. 
not been met and therefore PR1 was not a treaty US resident. Thus, according to PR1, the gain was made by the limited partners in PR1. The position of the tax authorities in Australia was instead that domestic provisions prevailed over the treaty and thus PR1 was the taxpayer making the gains. The Court ruled that since the Cayman partnership (PR1) was not a US treaty resident, the capital gains article did not authorize Australia to tax the gains of PR1. The Court also held that the limited partners of PR1 were the beneficial owners of the gains because the treaty provisions. ${ }^{6}$

\section{A. Application of the Convention to partnerships}

1.09 Domestic laws differ in the treatment of partnerships: in most countries partnerships are treated as tax-transparent entities (i.e. profits are directly attributed pro quota to the partners), while in some countries partnerships are treated as taxable units (i.e. tax-opaque entities or non tax-transparent entities). The Commentary ${ }^{7}$ complemented by the report by the CFA 'The Application of the OECD Model treaty to Partnerships' devotes considerable attention to the mismatches created by domestic laws which treat partnerships as taxable units or as fiscal transparent entities.

\section{Treaty entitlement for partnerships}

1.10 The preliminary issue is which CS has the treaty entitlement to tax partnerships, and the Commentary describes a situation in which the domestic laws of the RC (the country of residence of the partners) and of the SC (the country of the partnership) are not aligned in considering the partnership tax transparent, by looking at the treaty position of the partnership respectively in the $\mathrm{SC}$ and in the $\mathrm{RC}$.

1.11 If the partnership is treated as a company resident of CS1 (country where profits are produced) and 'liable to tax' therein (Art. 4 § 1), then the partnership is entitled to treaty benefits as a person, for example, the profits are subject to the dividends article when distributed. ${ }^{8}$ See for example infra at paras 1.94, 1. 114.

1.12 For example, in a Dutch case $X$, an individual resident of Belgium was a limited partner in a Dutch partnership conducting business in the Netherlands, and therefore was entitled to an eventual liquidation surplus upon the liquidation of the partnership. The issue was whether the Dutch partnership

6 Australia, Federal Court of Australia, Resource Capital Fund III LP v. Commissioner of Taxation, 26 April 2013, [2013] FCA 363.

7 Commentary to Art. 1 \$2-6.7.

8 Commentary to Art. $1 \S 5$. 
was a person for the purpose of the treaty. The Court held that the application of the residence article relating to partnerships did not depend on them being taxed as separate entities in the Netherlands and held that the Dutch partnership was a person for the purposes of the relevant treaty because its place of management was situated in the Netherlands.

The Court noted that if the application of the residence article relating to partnerships depended on the fact that they were taxed as separate entities in the Netherlands, then such a provision would be meaningless, which could not reasonably have been the aim of the treaty negotiators. ${ }^{9}$

It is worth noting that the Commentary to Art. 23 also addresses dividends distributions by partnerships in situations in which the SC (CS1) treats a partnership in the SC as a company, taxes the partnership on its income and taxes the distribution of profits by the partnership to its non-resident partners, while the $\mathrm{RC}$ of a partner (CS2) treats the partnership as fiscally transparent and taxes the partner on his share of the partnership's income. ${ }^{10}$ The Commentary notes that the $\mathrm{RC}$ is obliged by the treaty to give credit for tax that is levied in the SC on the partnership, which it treats as a separate taxable entity. ${ }^{11}$

The Commentary also takes the position that the $\mathrm{RC}$ is not obliged to provide 1.14 credit for the tax levied by the SC on a distribution which is not taxed in the $\mathrm{RC}$ arguing that since distribution is not taxed in the $\mathrm{RC}$, there is simply no $\operatorname{tax}$ in the $\mathrm{RC}$ against which to credit the tax levied by the SC upon the distribution. ${ }^{12}$

By contrast, if the partnership is fiscally transparent in CS2 (the country of residence of the partners) and is not 'liable to tax' therein, then the partnership is not entitled to treaty benefits and CS2 can tax the partners with respect to their share of income ${ }^{13}$ as the Convention does not restrict CS2 right to tax the partners who are its own residents. On other situations of tax-transparent partnerships see infra at paras 1.36, 1.65, 1.116, 1.119-1.120. The fact that a

9 The Netherlands, Hoge Raad der Nederlanden (Supreme Court), 29 084, 23 March 1994, Beslissingen in Belastingzaken, 1994, 192c.

10 Commentary to Art. $23 \S 69.1$.

11 Commentary to Art. $23 \S 69.2$.

12 Commentary to Art. $23 \S 69.3$.

13 Commentary to Art. $1 \S 5$. 
partnership is tax-transparent has various effects in terms of profit distributions (see infra at paras 6.11-6.12, 11.24-11.30, 1.116, 1.119-1.120), or in terms of charecterisation of income (see infra at paras 5.15-5.22, 4.1304.139).

1.16 A good example of treaty entitlement to partnerships and their partners is the leading UK case, Padmore in which the Court held that a resident partner although in theory taxable, was in fact protected by the treaty. $\mathrm{X}$, an individual resident of the UK, was a partner in Jersey-Pr, a firm carrying on business in Jersey. The firm did not have a PE in the UK, its business was dealt with by two managing partners both of whom were residents of Jersey but the majority of its partners were residents of the UK. The issue was whether $\mathrm{X}$ was taxable in the UK on his share of the profits of the partnership, but the preliminary question was whether Jersey-Pr was a 'person', i.e. a body of persons, which was resident of Jersey.

The Court held that in determining whether Jersey-Pr was resident of Jersey and thus within the scope of the treaty it was necessary to look at the location of its management and control, concluding that Jersey-Pr was resident of Jersey because it was managed and controlled in Jersey. The Court had to consider whether the treaty protection afforded to Jersey-Pr as a Jersey enterprise within the terms of the treaty, also flowed through to $X$ as a non-resident partner of the enterprise (i.e. the partnership). Because under English laws a partnership was not a legal entity distinct from that of the partners, the Court held that it was implicit that the treaty operated to exempt $X$ 's share in the profits of the Jersey partnership (Jersey-Pr):

The source of the income of an individual partner is the same as the source of income for all the partners, namely the trading operations of the partnership. If a partner is entitled, as a partner, to a share of the income of the partnership and that income is itself exempted from UK tax, (...) his share is similarly exempted in the absence of a direction to the contrary. That is because what he is entitled to (and what he would be taxed on if he were taxed) is a share of the profits of the enterprise and the Arrangement says that the profits of the enterprise are not subject to UK tax. ${ }^{14}$

1.17 Moreover when fiscally transparent partnerships or separate taxable entities are not a resident of the $\mathrm{RC}$ on the basis of its domestic laws, the partners liable to tax are the appropriate persons to claim treaty benefits because they are the recipient of the profits of the partnership. A good example of the lack of treaty entitlement to partnerships in these situations is Grundlingh, a case decided in

14 United Kingdom, Court of Appeal of England and Wales (Civil Division), Padmore v. Inland Revenue Commissioners, 19 May 1989, [1989] STC 493. 
South Africa. X, an individual resident of South Africa, was a partner in a law firm in Lesotho treated by domestic laws as a tax-transparent unit (i.e. the profits were attributed to the partners) and $X$ was taxed in Lesotho on his share of partnership profits. South African tax authorities also claimed that $\mathrm{X}$ was taxable in South Africa on the profits arising from the partnership because he was a tax resident of South Africa.

The issue was whether the Lesotho partnership was liable to tax in Lesotho and therefore a 'person' under the treaty. The Court found that X could not prove that the partnership was a person liable for tax in Lesotho, reasoning that on the basis of the persons article of the treaty, only persons who are residents for purposes of the treaty in either of South Africa and/or Lesotho were entitled to rely on the treaty. The Court also found that the Lesotho partnership was not liable to tax in Lesotho and that $X$ was the person liable to tax in Lesotho in respect of a share in the profits derived under the partnership agreement. ${ }^{15}$

When the partnership is entitled to treaty benefits as a person, the Convention does 1.19 not restrict CS1's right to tax the partners on their share of the income. For example, in a French case the Court held that profits derived by French partnerships with non-resident partners were taxable in France, that each partner was liable to tax according to its participation level and that the non-resident partners were not entitled to treaty protection specifically because under French domestic laws, a partnership has a separate legal and fiscal personality. ${ }^{16}$

Fiscally transparent partnerships do not qualify as residents of a CS under Art. 4 because the concepts of 'employer' and 'resident' for the purposes of Art. 15 $\S 2 \mathrm{~b}$ ) are applied at the level of the partners rather than at the level of a transparent entity. ${ }^{17}$

\section{Conflicts of allocation of taxing rights}

With regard to the taxation of partnerships there can be conflicts in the allocation of taxing rights of the two CSs. For example, if the SC treats a domestic partnership as fiscally transparent and the non-resident partner of such a partnership is resident of a State that taxes partnerships as companies, then the partner is not able to claim in the RC treaty benefits because that

15 South Africa, Free State High Court - Bloemfontein, J.J. Grundlingh v. Commissioner for the South African Revenue Service, 17 September 2009, 69 SATC 159.

16 France, Conseil d'État (Supreme Administrative Court), 317024, 11 July 2011, legifrance.gouv.fr/ affichJuriAdmin.do?oldAction=rechJuriAdmin\&idTexte=CETATEXT000024364405\&fastReqId $=192887$ $44 \&$ fastPos $=1$.

17 Commentary to Art. $1 \S 6.1$. 
income is not allocated in the $\mathrm{RC}$ of the partner. The same situation occurs if a partnership is not resident in the $\mathrm{SC}$ and is regarded by the $\mathrm{SC}$ as a separate taxable entity to which the income would be attributed.

1.22 The Commentary notes that in these situations the income allocation in the $R C$ is decisive: according to the Commentary conflicts of allocation are solved because income 'allocated' to partners is 'paid' in so far as partners satisfy the condition that income concerned is 'paid to a resident of the other CS' or 'derived by a resident of the other CS'. These conditions are satisfied even if the partnership is not resident in the SC and is regarded by the SC as a separate taxable entity to which the income would be attributed.

1.23 This position is confirmed by the Commentary to Art. 23 which affirms that when double taxation results from conflicts of qualifications, the $\mathrm{RC}$ is obliged to provide relief (credit or exemption). ${ }^{18}$ This situation is evidenced by a leading Belgian case in which a Belgian individual $(\mathrm{X})$ had a participation in a French Societé Civile Immobilière (SCI), a tax-transparent entity, which however had legal personality under French laws, whose main purpose was to acquire, administer and rent out immovable property located in France. The SCI was considered by Belgian laws as non-tax transparent because it had legal personality under French laws. ${ }^{19}$ The SCI distributed income to X and the French tax authorities treated the distributed income as a dividend, which was taxable only in Belgium (the treaty adopted taxation of dividends only in the country of recipient).

1.24 X claimed that the income he received was exclusively taxable in France on the basis of the relevant treaty article on income from immovable property. Under this article the term 'immovable property' has the meaning which it has under the laws of the CS in which the property is situated, i.e. in that case France. As France treated the SCI as tax-transparent, the income attributable to X had to be characterized as income from immovable property for treaty purposes as well. So the issue was whether the income characterization by the SC (in that case France) as income from immovable property should be decisive for treaty

18 For details see infra at 12.41-12.43 Commentary to Art. 23 § 32.2-3 observes:

(...) due to differences in the domestic laws between the $\mathrm{SC}$ and the $\mathrm{RC}$, income is taxed in accordance with the Convention, as interpreted and applied by the SC. In such a case, therefore, Art. 23A-23B require that relief from double taxation be granted by the $\mathrm{RC}$ notwithstanding the conflict of qualification resulting from these differences in domestic laws.

19 Under Belgian laws tax transparency was linked to the absence of legal personality and the legal personality of a foreign entity was determined in accordance with the domestic laws rules of the State in which the entity had its seat of effective management. Since the SCI had legal personality under French laws, it was treated in Belgium as a non-transparent entity for tax purposes. 
purposes. The Court accepted the claim advanced by $\mathrm{X}$ and held that the treaty notion of 'immovable property' was defined by the laws of the State in which it was situated (France). Therefore not only was the SCI treated in Belgium as a transparent entity for treaty purposes (in spite of the fact that the SCI was treated as a non-transparent entity under Belgian domestic laws), but also the income attributed to $\mathrm{X}$ was treated under the relevant treaty rule as income from immovable property exclusively taxable in the CS where the immovable property was situated (i.e. France). ${ }^{20}$

\section{Triangular cases}

The Commentary also addresses triangular cases involving partnerships. If a partnership is established in country B, the partners are resident in country A, and the allocated partnership income arises in a third country, then the partners may claim the benefits of the treaty between countries $A$ and $B$. Moreover if the partnership is taxed as a resident of country $\mathrm{B}$, then the partnership may claim benefits of the treaty between country B and the third country (if any).

In the situation of 'double benefits' country B in its capacity as the $\mathrm{SC}$ may not impose taxation inconsistent with the treaty between country A and the SC, or inconsistent with the treaty between country B and the SC. If different rates (or a different treatment) are provided for in the treaty between country $\mathrm{A}$ and the $\mathrm{SC}$, or in the treaty between country B and the SC, then the lower rate (or the better treatment) applies.

The Commentary remarks that the CSs may agree to introduce special provisions according to which only partnerships may claim benefits, not partners. Under these provisions if a partnership is transparent in country B, then no benefits are available to it under the treaty between country $B$ and the SC. Moreover, if income of the partnership is not allocated to the partner in A, then no benefits are available under the treaty between country A and the SC or the treaty between the country of the RC and the SC.

By contrast, under these provisions, if a partnership is not a resident of the SC because it is not liable to tax therein and the partners are liable to tax in their $\mathrm{RC}$ (i.e. country A) on their share of the partnership's income, then country A applies the treaty between the $\mathrm{RC}$ and the $\mathrm{SC}$ as if those partners had earned income directly. In this case the classification of income for the purposes of

20 See: Belgium, Hof van Cassatie/Cour de Cassation (Supreme Court), F030006F, 2 December 2004, Tijdschrift voor Fiscaal Recht, 2005, 304, discussed infra at 5.08-5.12 
allocative rules (Artt. 6-21) is not modified by the fact that the income flows through the partnership.

1.29 The Commentary acknowledges that difficulties may arise and refers to $\S 19.1$ of Commentary to Art. 5 and $\S \S 6.1$ and 6.2 of Commentary to Art. 15. Moreover in case of conflicts of qualification $\S \S 32.1$ and 56.1 of the Commentary to Art. 23 apply (for details see infra at paras 12.33-12.53).

\section{B. Application of the Convention to CIVs}

\section{Treaty eligibility of CIVs}

1.30 The main question addressed by the Commentary is the treaty eligibility of CIVs, i.e. whether a CIV should qualify for treaty benefits in its own right. ${ }^{21}$ To do so a CIV would have to qualify as a 'person' and 'resident' of a CS for the purposes of the dividends or interest article being the 'beneficial owner' of the income. In light of the fact that there are differences in the tax treatment of CIVs from country to country the problem that often arises is whether a CIV is a 'person' or whether a CIV is a 'resident'. Whether a CIV is a 'person' depends on legal form of CIV, i.e. whether it is regulated by domestic laws as a taxable unit. Whether a CIV is a 'resident' depends on its tax treatment in the State in which it is established, on the basis of the criteria established by domestic laws.

\section{Policy issues raised by the current treatment of CIVs}

1.31 The Commentary addresses these policy issues and advances five approaches proposing possible treaty clauses respectively based on the following rules:

1. CIVs are expressly entitled to treaty benefits by the treaty in so far as they are attributed the quality of being a person for treaty purposes;

2. CIVs are entitled to treaty benefits under the 'equivalent beneficiaries' requirement;

3. CIVs are entitled to treaty benefits on the condition that CIV investors are residents of the same country as the CIV;

4. CIVs are entitled to treaty benefits by adopting a look-through approach which ensures that the benefits of investors are maintained; and

5. CIVs are entitled to treaty benefits if they are publicly traded.

21 A special report was issued by the OECD: The Granting of Treaty Benefits with Respect to the Income of CIV, complementing $\S \S 6.8-6.30$ of Commentary to Art. 1. 
CIV rules are essentially inspired to the beneficial owner approach for dividends (see infra at paras 1.62-1.89) and to the improper use of treaty policies (see infra at paras 1.39-1.60), with adaptations.

\section{a. CIVs expressly entitled to treaty benefits}

According to the first approach CIVs are expressly entitled to treaty benefits in so far as they are attributed the quality of being a person for treaty purposes. The Commentary notes however that there may be problems caused by divergent treatment of CIVs in the CSs which create potential abuse. ${ }^{22}$ For example, in a Finnish case addressing the issue whether a Luxembourg SICAV fund was subject to tax in Luxembourg and, therefore, a resident of Luxembourg under the residence article of the Finland-Luxembourg treaty, the Court held that the SICAV fund was entitled to treaty benefits because it was a corporation subject to tax and therefore a resident of Luxembourg for tax purposes, although exempt from Luxembourg tax on the basis of domestic laws. ${ }^{23}$

\section{b. 'Equivalent beneficiaries'}

According to the second approach CIVs are entitled to treaty benefits under an 'equivalent beneficiary' comparable which is established between: (i) a beneficiary of CIV income resident of the CS in which the CIV is established; and (ii) a beneficiary of CIV income resident of any other State with which the CS in which the income arises has a treaty providing for effective information exchange and subject to the same tax treatment on the CIV income. ${ }^{24}$ In practice the treatment of the CIV under the treaty between the

Notwithstanding the other provisions of this Convention, a collective investment vehicle which is established in a CS and which receives income arising in the other CS shall be treated, for purposes of applying the Convention to such income, as an individual that is a resident of the CS in which it is established and as the beneficial owner of the income it receives (provided that, if an individual who is a resident of the first-mentioned State had received the income in the same circumstances, such individual would have been considered to be the beneficial owner thereof). For purposes of this section, the term 'collective investment vehicle' means, in the case of [State A], a [ ] and, in the case of [State B], a [ ], as well as any other investment fund, arrangement or entity established in either CS which the Competent Authorities of the CSs agree to regard as a collective investment vehicle for purposes of this section.

23 Finland, Korkein Hallinto-oikeus (Supreme Administrative Court), 2004:111, 22 December 2004, finlex.fi/ fi/oikeus/kho/vuosikirjat/2004/200403345.

24 Commentary to Art. $1 \S 6.21$ :

For purposes of this section: the term 'equivalent beneficiary' means a resident of the CS in which the CIV is established, and a resident of any other State with which the CS in which the income arises has an income treaty that provides for effective and comprehensive information exchange who would, if he received the particular item of income for which benefits are being claimed under this Convention, be entitled under that Convention, or under the domestic laws of the CS in which the income arises, to a rate of tax with respect to that item of income that is at least as low as the rate claimed under this Convention by the CIV with respect to that item of income. 
$\mathrm{SC}$ on income and the $\mathrm{RC}$ of the CIV recipient is applied to a recipient in a third country only if there is equivalent treatment of both beneficiaries on such income. This requirement is essentially to prevent treaty abuse. ${ }^{25}$

\section{c. CIV investors residents of CIV's CS}

1.34 According to the third approach CIVs are entitled to treaty benefits on the condition that CIV investors are resident of the same country of the CIV. ${ }^{26}$ In practice the treatment of the CIV under the treaty between the SC and the $\mathrm{RC}$ of the $\mathrm{CIV}$ recipient is applied only if the recipient is resident of the treaty $\mathrm{RC}$. This requirement is also to prevent treaty abuse.

\section{d. Look-through, benefits of investors maintained}

1.35 According to the fourth approach CIVs are entitled to treaty benefits by adopting a look-through approach which ensures that investors in CIVs do not lose the benefit of the preferential rates to which they would have been entitled had they invested directly. ${ }^{27}$ In practice the treatment of the CIV under the treaty between the $\mathrm{SC}$ and the $\mathrm{RC}$ of the $\mathrm{CIV}$ recipient is applied

Notwithstanding the other provisions of this Convention, a 'collective investment vehicle' which is established in a CS and which receives income arising in the other CS shall be treated for purposes of applying the Convention to such income as an individual who is a resident of the CS in which it is established and as the beneficial owner of the income it receives (provided that, if an individual who is a resident of the first-mentioned State had received the income in the same circumstances, such individual would have been considered to be the beneficial owner thereof), but only to the extent that the beneficial interests in the collective investment vehicle are owned by equivalent beneficiaries.

Commentary to Art. 1 § 6.26:

Notwithstanding the other provisions of this Convention, a 'collective investment vehicle' which is established in a CS and which receives income arising in the other CS shall be treated for purposes of applying the Convention to such income as an individual who is a resident of the CS in which it is established and as the beneficial owner of the income it receives (provided that, if an individual who is a resident of the first-mentioned State had received the income in the same circumstances, such individual would have been considered to be the beneficial owner thereof), but only to the extent that the beneficial interests in the collective investment vehicle are owned by residents of the CS in which the collective investment vehicle is established.

For purposes of this section, the term 'collective investment vehicle' means, in the case of [State A], a [ ] and, in the case of [State B], a [ ], as well as any other investment fund, arrangement or entity established in either CS which the Competent Authorities of the CSs agree to regard as a collective investment vehicle for purposes of this section.

Commentary to Art. 1 § 6.27:

A collective investment vehicle described in sub§c) which is established in a CS and which receives income arising in the other CS shall not be treated as a resident of the CS in which it is established, but may claim, on behalf of the owners of the beneficial interests in the collective investment vehicle, the tax reductions, exemptions or other benefits that would have been available under this Convention to such owners had they received such income directly. A collective investment vehicle may not make a claim under sub§ a) for benefits on behalf of any owner of the beneficial interests in such collective investment vehicle if the owner has itself made an individual claim for benefits with respect to income received by the collective investment vehicle. 
only to the recipient resident of the $\mathrm{RC}$ but not to the CIV, which is viewed as a pass-through. For example, in an Austrian case the issue was whether the Austrian Fund or the Austrian unit holder was entitled to apply for a refund of the Finnish withholding tax levied in excess of the rate of 10 per cent under the dividends treaty article, and the Court held that the Austrian unit holder was entitled to treaty benefits, since he was deemed to be the actual recipient of dividends and a person who was a resident of Austria for tax purposes. ${ }^{28}$

In a similar Finnish case a company resident of Finland invested in a

Luxembourg open-ended FCP fund (fonds commun de placement), which under Luxembourg laws was a partnership managed by a separate company and thus was not a separate legal entity from the persons making the initial investments and, could not acquire rights or be subject to obligations independently. Under Luxembourg laws the FCP was held as a transparent entity and was exempt from tax, but subject to a Luxembourg tax levied on 6 per cent of the net assets. The issue was whether the FCP was a transparent entity for Finnish tax purposes, i.e. whether the Finland-Luxembourg treaty or Finland-US treaty was applicable to the US source dividends and interest received through the FCP fund.

The Court observed that the Finland-Luxembourg treaty did not contain a separate provision for an investment fund like the FCP and that in order to be eligible for treaty benefits a person needs to be a resident who is subject to tax under the tax rules of a CS. Since the FCP fund was not subject to tax on income in Luxembourg, the FCP could not be deemed to be tax resident there. The Court then observed that the FCP's management agreement contained an automatic distribution provision, implying that all profits had to be distributed annually to the unit holders. Consequently, the Court decided that the FCP was, under the Finland-Luxembourg treaty, a transparent entity even if the FCP was considered a corporation under Finnish domestic laws. The Court concluded that the Finland-US treaty applied to the income that a Finnish resident company received through the FCP, provided that such company was the beneficial owner of the income as defined in the Finland-US treaty. ${ }^{29}$

28 Finland, Hallinto-oikeus Helsinki (Regional Administrative Court, Helsinki), 2003 03/0577/1, 9 September 2003, finlex.fi/fi/oikeus/hao/2003/20032881?search\%5Btype\%5D=pika\&search\%5Bpika\%5D=verosopimus.

29 Finland, Korkein Hallinto-oikeus (Supreme Administrative Court), 2004:116, 22 December 2004, finlex.fi/ fi/oikeus/kho/vuosikirjat/2004/200403359. 


\section{e. Publicly traded CIVs}

1.38 According to the fifth approach CIVs are entitled to treaty benefits if they are publicly traded, based on the concept that a publicly traded CIV cannot be used effectively for treaty shopping because the shareholders or unit holders of such a CIV cannot individually exercise control over it. ${ }^{30}$

\section{Improper use of the Convention}

\section{Introduction}

1.39 Domestic anti-abuse rules are artificial legal constructs aimed at securing the benefit of domestic laws and treaties (treaty shopping). This aim is aligned with one of the purposes of treaties, which is to prevent tax avoidance and evasion. As a consequence the Commentary takes the position that, as a principle, domestic anti-abuse rules do not conflict with treaties and that benefits of treaties cannot be granted when transactions constitute an abuse of such treaties. ${ }^{31}$

1.40 In practice, therefore, an abuse of a treaty is as an abuse of domestic laws. There is however the need for the inclusion of anti-abuse rules in treaties, such as the concept of 'beneficial owner' (in Artt. 10,11, and 12), the look-through approach adopted by Art. $17 \S 2$, the requirement that a subsidiary be managed by the parent in such a way that the subsidiary is not a PE of the parent. To address those issues the CFA issued two reports ('Treaties and the Use of Base Companies' and 'Treaties and the Use of Conduit Companies') which are now included in the Commentary to Art. 1.

\section{Approaches to the improper use of the treaties}

1.41 The Commentary addresses the policy issues raised by improper use of the treaties and advances the following five approaches proposing possible treaty clauses:

1. look-through approach;

30 Commentary to Art. $1 \S 6.32$ :

Notwithstanding the other provisions of this Convention, a collective investment vehicle which is established in a CS and which receives income arising in the other CS shall be treated for purposes of applying the Convention to such income as an individual who is a resident of the CS in which it is established and as the beneficial owner of the income it receives (provided that, if an individual who is a resident of the first-mentioned State had received the income in the same circumstances, such individual would have been considered to be the beneficial owner thereof), if the principal class of shares or units in the collective investment vehicle is listed and regularly traded on a regulated stock exchange in that State.

31 Commentary to Art. $1 \S 9$. 
2. subject-to-tax approach;

3. channel approach;

4. bona fide safeguard clauses; and

5. limitation-of-benefits approach.

The judicial applications of these policies about improper use of the treaties are often conflated with the concept of beneficial ownership for dividends (see infra at paras 1.62-1.89), interest (see infra at paras 1.90-1.108), royalties (see infra at paras 1.109-1.123), income of entertainers/sportspersons (see infra at paras 1.124 and 9.50-9.87), and capital gains (see infra at paras 1.118-1.123 and 5.68).

\section{a. Look-through approach}

The look-through approach disallows treaty benefits to a company not owned, directly or indirectly, by residents of the RC (State of which the company is a resident) and can be adopted in treaties with countries that have no or very low taxation and where little business activity is carried on, but still requires to be complemented by derogations to safeguard bona fide business activities.

The proposed language of a treaty look-through clause is the following:

A company that is a resident of a CS shall not be entitled to relief from taxation under the Convention with respect to any item of income, gains or profits if it is owned or controlled directly or through one or more companies, wherever resident, by persons who are not residents of a CS. ${ }^{32}$

In practice when income is paid to an intermediary company which in turn pays that income to a recipient, the treatment accorded by the treaty between the SC and the RC of the recipient is applied only to the recipient which is resident of the same CS as the intermediary company, but not to the recipient which is not resident of the same CS as the intermediary company, which in such a case is viewed as a pass-through.

National Courts often apply the look-through approach. For example, in Russel, an Australian case, X, an individual resident of Australia was the sole shareholder of $\mathrm{Nz}-\mathrm{Co}$, a company resident of New Zealand. Nz-Co entered into a contract with Aus-Co, a company resident of Australia, to procure the supply of X's services to Aus-Co for a yearly fee plus contributions to a pension fund and payments for various leave entitlements. $\mathrm{X}$ argued that the income assessed in the hands of $\mathrm{X}$ was in fact profits of $\mathrm{Nz}-\mathrm{Co}$ and therefore 
taxation of those profits in Australia, in the absence of a $\mathrm{PE}$ of Nz-Co therein, was contrary to the business profits article of the Australia-New Zealand treaty.

1.45 The issue was whether the covered persons article and the business profits article of the treaty prevented taxation of the income in the hands of $\mathrm{X}$ under Australian rules which attributed income to the final recipient (in that case $\mathrm{X}$ ). The Court determined that the Australian personal service income rules applied: those rules attributed the income to $\mathrm{X}$ and not to $\mathrm{Nz}-\mathrm{Co}$ and clarified that the treaty would protect the profits of $\mathrm{Nz}-\mathrm{Co}$ from Australian taxation had the income in question formed part of Nz-Co's profits. ${ }^{33}$ The lookthrough approach is also effectively used in many cases adopting the beneficial ownership concept and in conduit cases concerning dividends, interest and royalties to protect the tax prerogatives of the treaty the $\mathrm{SC}$ and prevent treaty shopping (see infra at paras 1.62-1.124).

\section{b. Subject-to-tax approach}

1.46 According to the subject-to-tax approach, treaty benefits are granted in the SC only if the income is subject to tax in the RC. This approach can be used in States with well-developed economic structures and complex laws, but bona fide derogations for flexibility are needed, also it does not provide adequate protection against advanced tax avoidance schemes such as 'stepping-stone strategies'.

1.47 The proposed language of a treaty subject-to-tax clause is the following:

Where income arising in the $\mathrm{SC}$ is received by a company resident of the $\mathrm{RC}$ and one or more persons not resident in that the $\mathrm{RC}$ have directly or indirectly or through one or more companies, wherever resident, a substantial interest in such company, in the form of a participation or otherwise, or exercise directly or indirectly, alone or together, the management or control of such company, any provision of this Convention conferring an exemption from, or a reduction of, tax shall apply only to income that is subject to tax in the $\mathrm{RC}$ under the ordinary rules of its domestic laws. ${ }^{34}$

The subject-to-tax approach has been in practice used in cases about beneficial ownership of dividends (see infra at paras 1.80-1.81), and royalties (see infra at para 1.116).

33 Australia, High Court of Australia, Anthony Whitworth Russell v. Commissioner of Taxation of Commonwealth of Australia, 10 February 2012, [2012] HCA Trans 21.

34 Commentary to Art. $1 \S 15$. 


\section{c. Channel approach}

The channel approach singles out cases of improper use with reference to the conduit arrangements themselves and is aimed at counteracting 'steppingstone' schemes. The proposed language of a treaty channel clause is the following:

Where income arising in a CS is received by a company that is a resident of the other CS and one or more persons who are not residents of that other CS have directly or indirectly or through one or more companies, wherever resident, a substantial interest in such company, in the form of a participation or otherwise, or exercise directly or indirectly, alone or together, the management or control of such company, any provision of this Convention conferring an exemption from, or a reduction of, tax shall not apply if more than 50 per cent of such income is used to satisfy claims by such persons (including interest, royalties, development, advertising, initial and travel expenses, and depreciation of any kind of business assets including those on immaterial goods and processes). ${ }^{35}$

These clauses are found for example, in the treaties entered into by Switzerland and the US and should be supplemented by a bona fide safeguard clause. The channel approach has been in practice used in cases about beneficial ownership of interest (see infra at paras 1.99-1.104), and royalties (see infra at paras 1.110-111) by looking at the criterion of real disposition of funds.

\section{d. Bona fide safeguard clauses}

Bona fide safeguard clauses are aimed at ensuring that treaty benefits are granted only in bona fide cases. The proposed language of a bona fide provision is the following:

The foregoing provisions (i.e. anti-abuse rules) shall not apply where the company establishes that the principal purpose of the company, the conduct of its business and the acquisition or maintenance by it of the shareholding or other property from which the income in question is derived, are motivated by sound business reasons and do not have as primary purpose the obtaining of any benefits under this Convention.

For example, in an Austrian case Austria-Co, a company resident of Austria, established two Irish subsidiaries resident of Ireland, which received only passive income and were subject to a tax rate of 10 per cent. At the level of the Austrian parent company, the Irish subsidiaries' profit distributions were tax exempt under Austrian laws, which provided for an exemption for participations of 25 per cent and more. Also the Austria-Ireland treaty provided for a participation exemption. The Court held that a structure whereby an Austrian 
company interposes a subsidiary within the Irish favourable tax regime to make combined use of a reduced tax rate in Ireland and the participation exemption in Austria falls under the domestic anti-abuse provision and that the lack of a specific anti-abuse provision in a treaty does not prevent a CS from protecting itself against unjustified exploitation of treaty benefits. ${ }^{36}$

1.51 A bona fide provision usually includes a general clause which is complemented by different additional provisions (activity provisions, amount of tax provisions, stock exchange provisions, alternative relief provisions) which can be combined in different ways. ${ }^{37}$ Bona fide safeguard clauses have been in practice used as indicators in cases about beneficial ownership of dividends (see infra at paras 1.63-1.64), and interest (see infra at paras 1.105-1.118) by looking at the criterion of real disposition of funds.

\section{e. Limitation-of-benefits approach}

1.52 The limitation-of-benefits approach addresses 'treaty shopping' in a comprehensive way by adopting a complex multi-test clause (so-called 'LOB clause') which is found for example in the US treaties. According to such a clause a resident of a CS who derives income from the other CS is entitled to all the benefits of the treaty otherwise accorded to residents of a CS only if such a resident is a 'qualified person' as defined by the various tests of the LOB clause and also meets the other conditions of the treaty for the obtaining of such benefits. The Commentary proposes a LOB clause. ${ }^{38}$

36 Austria, Verwaltungsgerichtshof (Supreme Administrative Court), 2001/13/0018 and 0019, 10 August 2005， ris.bka.gv.at/JudikaturEntscheidung.wxe?Abfrage=Vwgh\&Dokumentnummer=JWT_2001130018_ 20050810 X00.

37 19. Activity provision: 'The foregoing provisions shall not apply where the company is engaged in substantive business operations in the CS of which it is a resident and the relief from taxation claimed from the other CS is with respect to income that is connected with such operations.'

Amount of tax provision: 'The foregoing provisions shall not apply where the reduction of tax claimed is not greater than the tax actually imposed by the CS of which the company is a resident.'

Stock exchange provision:

The foregoing provisions shall not apply to a company that is a resident of a CS if the principal class of its shares is registered on an approved stock exchange in a CS or if such company is wholly owned - directly or through one or more companies each of which is a resident of the first-mentioned State - by a company which is a resident of the first-mentioned State and the principal class of whose shares is so registered.

\section{Alternative relief provision:}

In cases where an anti-abuse clause refers to non-residents of a CS, it could be provided that the term shall not be deemed to include residents of third countries that have income conventions in force with the CS from which relief from taxation is claimed and such conventions provide relief from taxation not less than the relief from taxation claimed under this Convention.

38 Commentary to Art. $1 \S 20$. 


\section{Provisions aimed at different types of improper use of the treaties}

The Commentary also describes other types of provisions addressing different types of improper use of the treaties and advances the following approaches, proposing possible treaty clauses:

1. provisions aimed at entities benefiting from preferential tax regimes;

2. provisions aimed at particular types of income;

3. anti-abuse rules dealing with source taxation of specific types of income;

4. provisions aimed at preferential regimes introduced after the signature of the treaty; and

5. remittance based taxation.

a. Provisions aimed at entities benefiting from preferential tax regimes

The provisions aimed at entities benefiting from preferential tax regimes adopt an ad hoc exclusion approach and a preferential tax regime approach.

\section{(i) Ad hoc exclusion approach}

The ad hoc exclusion approach denies treaty benefits to companies enjoying tax privileges in their $\mathrm{RC}$ and is based on the following proposed clause: 'No provision of the Convention conferring an exemption from, or reduction of, tax shall apply to income received or paid by a company as defined under section ... of the ... Act, or under any similar provision enacted by ... after the signature of the Convention.' ${ }^{39}$ The scope of this provision could be further limited by referring only to specific types of income, such as dividends, interest, capital gains, or directors' fees.

\section{(ii) Preferential tax regime approach}

The preferential tax regime approach denies treaty benefits to entities that would otherwise qualify as residents of a CS but which enjoy, in that State, a preferential tax regime restricted to foreign-held entities (i.e. which are not available to entities that belong to residents of that State) and is based on the following proposed clause:

Any company, trust or partnership that is a resident of a CS and is beneficially owned or controlled directly or indirectly by one or more persons who are not residents of that State shall not be entitled to the benefits of this Convention if the amount of the tax imposed on the income (or capital) of the company, trust or partnership by that State (after taking into account any reduction or offset of the amount of tax in any manner, including a refund, refund, contribution, credit or allowance to the company, trust or partnership, or to any other person) is substantially lower than the amount that would 
be imposed by that State if all of the shares of the capital stock of the company or all of the interests in the trust or partnership, as the case may be, were beneficially owned by one or more residents of that State. ${ }^{40}$

The rationale of the preferential tax regime approach is found in cases about limitations to the reduced treaty withholding tax on outbound dividends (see infra at paras 6.06-6.07), and interest (see infra at para 6.60).

\section{b. Provisions aimed at particular types of income}

1.57 Provisions aimed at particular types of income are essentially passive income clauses which deny treaty benefits in respect of income that is subject to low or no tax under a preferential tax regime. A passive income clause covers income derived from activities which do not require a substantial presence in that State, ${ }^{41}$ and also defines what is a preferential tax regime. ${ }^{42}$ Judicial applications of this approach are found in cases about dividends (see infra at paras 6.06-6.10), royalties (see infra at paras 7.04-7.13) and interest (see infra at para 6.58).

\section{c. Anti-abuse rules dealing with source taxation of specific types of income}

1.58 Anti-abuse rules dealing with source taxation of specific types of income adopt the main purpose approach and deny the benefits of specific articles of the treaties that restrict source taxation where transactions (Artt. 10, 11, 12 and 21) have been entered into for the main purpose of obtaining these benefits. ${ }^{43}$

40 Commentary to Art. $1 \S 21.2$.

41 Commentary to Art. $1 \S 21.3$ The proposed language of a bona fide provision is the following:

1.The benefits of this Convention shall not apply to income which may, in accordance with the other provisions of the Convention, be taxed in a CS and which is derived from activities the performance of which do not require substantial presence in that State, including: such activities involving banking, shipping, financing, insurance or electronic commerce activities; or activities involving headquarter or coordination centre or similar arrangements providing company, or group administration, financing or other support; or activities which give rise to passive income, such as dividends, interest and royalties where, under the laws or administrative practices of that State, such income is preferentially taxed and, in relation thereto, information is accorded confidential treatment that prevents the effective EI.

42 Commentary to Art. $1 \S 21.3$ :

2. For the purposes of $\S 1$, income is preferentially taxed in a CS if, other than by reason of the preceding articles of this Agreement, an item of income: is exempt from tax; or is taxable in the hands of a taxpayer but that is subject to a rate of tax that is lower than the rate applicable to an equivalent item that is taxable in the hands of similar taxpayer who are residents of that State; or benefits from a credit, rebate or other concession or benefit that is provided directly or indirectly in relation to that item of income, other than a FTC.

43 Commentary to Art. $1 \S 21.4$ :

this article shall not apply if it was the main purpose or one of the main purposes of any person concerned with the creation or assignment of the [Art. 10: 'shares or other rights'; Art. 11: 'debt-claim'; Artt. 12 and 21: 'rights'] in respect of which the [Art. 10: 'dividends'; Art. 11: 'interest'; Art. 12 'royalties' and Art. 21: 'income'] is paid to take advantage of this article by means of that creation or assignment. 


\section{d. Provisions aimed at preferential regimes introduced after the signature of the treaty}

The provisions aimed at preferential regimes introduced after the signature of the treaties adopt the special tax benefit approach to protect a CS from having to give treaty benefits with respect to income benefiting from a special regime for certain offshore income introduced after the signature of the treaty, ${ }^{44}$ or adopt the 'substance-over-form', 'economic substance' and general anti-abuse rules as established by domestic laws. ${ }^{45}$

\section{e. Remittance based taxation}

Remittance based taxation is introduced by a resident non-domiciled provision: a resident non-domiciled is only taxed on income derived from sources outside the State to the extent that this income is effectively repatriated, or remitted and is based on the following provision:

Where under any provision of this Convention income arising in the SC is relieved in whole or in part from tax in that $\mathrm{SC}$ and under the laws in force in the $\mathrm{RC}$ a person, in respect of the said income, is subject to tax by reference to the amount thereof which is remitted to or received in that $\mathrm{RC}$ and not by reference to the full amount thereof, then any relief provided by this Convention shall apply only to so much of the income as is taxed in the RC. ${ }^{46}$

\section{The concept of 'beneficial owner'}

\section{General aspects}

The Commentary provides common concepts in regard to the beneficial owner of, respectively, dividends, interest, royalties and capital gains. Essentially the Commentary clarifies that the term 'beneficial owner' is 'not used in a narrow technical sense (such as the meaning that it has under the trust laws of many common law countries), rather, it should be understood in its context, in particular in relation to the words 'paid ... to a resident', and in light of the object and purposes of the Convention, including avoiding double taxation and the prevention of fiscal evasion and avoidance. ${ }^{47}$ At the same time national Courts have autonomously developed judicial criteria to identify

44 Commentary to Art. $1 \S 21.5$ :

The benefits of Artt. 6 to 22 of this Convention shall not accrue to persons entitled to any special tax benefit under a law of either one of the States which has been identified in an exchange of notes between the States; or any substantially similar law subsequently enacted. 
beneficial ownership and conduit structures in the different economic and legal contexts in which respectively, dividends, interest, royalties and capital gains are paid or realized within cross-border group structures. So the analysis developed below looks at the specific judicial applications in these different areas.

The beneficial ownership concept in judicial applications is often aligned with the policies discussed in the Commentary about the improper use of treaties (see supra at paras 1.39-1.61).

\section{Beneficial owner and different types of income (dividends, interest, royalties) \\ a. Beneficial owner of dividends \\ (i) Indicators of beneficial ownership of dividends developed by case law}

1.62 The concept of the beneficial owner of dividends plays an important role in determining whether the reduced withholding tax can be actually applied under a bilateral treaty between the payer of dividends and a direct shareholder when dividends received by that direct shareholder are then re-distributed to other shareholders up the chain of controlled companies, particularly when holding companies are involved. For example, in a Swiss case the Court held that the beneficial owner was the person who had the benefit of an advantage, a performance, etc., i.e. the person who can receive the benefit of a performance, as opposed to the person which just initially receives the benefit but then transfers it to a third person. So a recipient which transfers received dividends to a third person without being in a position to dispose of the benefit is not a beneficial owner. The beneficial owner is, thus, the person that has the economic benefit of a dividend, as opposed to a 'conduit' company which is placed as an intermediary between the payer of the income and the ultimate recipient. ${ }^{48}$

1.63 In the leading case, Prérost, decided in Canada the Court noted that a definition of 'beneficial ownership' was not provided either by the Model or by the relevant treaty or by Canadian laws, but could be interpreted in the light of the OECD 'Conduit Companies Report' and the Commentary. So the Court rejected the definition advanced by the tax authorities (according to which the 'beneficial owner' is 'the person who can, in fact, ultimately benefit from the dividends') because it found that such a definition was not consistent with the Commentary, which stated that the 'beneficial owner' is 'the person who

48 Switzerland, Commission fédérale de recours en matière de contributions (Federal Tax Appeal Commission), VPB 65.86, 28 February 2001, Steuerreoue, 2002, 30. 
receives the dividends for his or her own use and enjoyment and assumes the risk and control of the dividends he or she received'.

In Prévost the decision was that DutchCo, a company resident of the

Netherlands, was actually the 'beneficial owner' of the dividends paid by a company resident of Canada and, consequently, was entitled to treaty benefits of the Canada-Netherlands treaty (i.e. the reduced withholding tax rate). This position was supported by several indicators of beneficial ownership such as: the relationship between DutchCo and its shareholders was not one of agency, or mandate nor one where the property was in the name of a nominee; DutchCo was not 'a conduit for another person' as it had discretion on how to manage its funds and there was no automatic flow of funds to its shareholders; DutchCo effectively carried on business under Dutch laws; DutchCo's shareholders were not entitled to take legal action against it because of the lack of a dividend re-distribution; and finally, the DutchCo deed of incorporation did not include an obligation to pay dividends to its shareholders. Furthermore, DutchCo was the registered owner of the Canadian company shares, paid for the shares and owned the shares for itself. It followed that when the dividends were received by DutchCo in respect of shares it owned, the dividends were the property of the DutchCo and were available to its creditors. ${ }^{49} \mathrm{~A}$ similar approach is found in the bona fide safeguard clauses suggested by the Commentary (see supra at paras 1.49-1.51).

The Commentary also clarifies that when an item of income is paid to a resident of a CS acting in the capacity of agent or nominee it would be inconsistent with the object and purpose of the Convention for the SC to grant relief or exemption merely on account of the status of the direct recipient of income as a resident of the other CS. When the treaty is not applied by the $\mathrm{SC}$ no potential double taxation arises as a consequence of the status of agent or nominee of the recipient, since such an entity is not treated as the owner of income for tax purposes in the RC. ${ }^{50}$ An Italian case delves into the details of the agent concept. A pension fund, resident of Japan, acquired a participation in PR, a US limited partnership which, in turn, purchased shares in Italian companies. JapBank, a bank resident of Japan, managed funds of JapFund and held the participation of JapFund in PR, acting as an agent of JapFund. Italian companies paid dividends to JapFund which then claimed the reduced withholding tax under the Italy-Japan treaty, which did not contain a beneficial owner clause. The Court denied the application of the Japan-Italy treaty to JapFund holding that the dividends were paid to PR, a resident of the US and

49 Canada, Tax Court of Canada, Prévost Car Inc. v. Her Majesty the Queen, 22 April 2008, 2008 TCC 231.

50 Commentary to Art. $10 \S 12.2$. 
that the fact that JapFund was the ultimate beneficiary of the dividends could not justify the application of the dividends article of the relevant treaty. The Court added that JapFund did not receive the dividends itself as they were paid to (and received by) PR, so that JapFund only received the final outcome of the investment made through the bank, with the result that the dividends article of the Japan-Italy treaty was not applicable. The Court added that the fact that the participation in PR was held by JapBank acting as an agent of JapFund indicated that the fund was the beneficiary of the income. The Court emphasized that it was irrelevant that PR was treated as tax-transparent in the US because the PR shares were held by JapBank and not by the JapFund, so the former rather than the latter, might have claimed treaty benefits (which it did not). ${ }^{51}$

1.66 The Commentary specifies that if a resident of a CS simply acts as a 'conduit' for another person who in fact receives benefit of the income, then it would be inconsistent with the object and purpose of the Convention for the SC to grant relief or exemption. ${ }^{52}$ The term 'conduit' is further defined in the CFA report 'Double Taxation Treaties and Use of Conduit Companies' which clarifies that 'a conduit company cannot normally be regarded as beneficial owner if, though formal owner, it has, as a practical matter, very narrow powers which render it, in relation to income concerned, a mere fiduciary or administrator acting on account of interested parties'. So limitation of the tax in the SC is available only when an intermediary, such as an agent or nominee located in a CS or in a third country, is interposed between beneficiary and payer, and qualifies as a beneficial owner resident of the other CS. ${ }^{53}$

\subsection{According to the Commentary:}

the direct recipient of the dividend is not the 'beneficial owner' because that recipient's right to use and enjoy the dividend is constrained by a contractual or legal obligation to pass on the payment received to another person (...) in substance, the recipient clearly does not have the right to use and enjoy the dividend unconstrained by a contractual or legal obligation to pass on the payment received to another person. (...) Where the recipient of a dividend does have the right to use and enjoy the dividend unconstrained by a contractual or legal obligation to pass on the payment received to another person, the recipient is the 'beneficial owner' of that dividend. ${ }^{54}$

51 Italy, Corte Suprema di Cassazione (Supreme Court), 4600, 1 March 2009, Diritto e Fiscalita' dell'Assicurazione, 2009, 3, 1095.

52 Commentary to Art. $10 \S 12.3$.

53 Commentary to Art. $10 \S 12.2$.

54 Commentary to Art. $10 \S 12.4$. 
Moreover the Commentary affirms that "the meaning of "beneficial owner" (...) must be distinguished from the different meaning that has been given to that term in the context of other instruments that concern the determination of the persons (typically the individuals) that exercise ultimate control over entities or assets. ${ }^{55}$

These indicators highlighted by the Commentary are found in judicial applications that conclude that an intermediary entity factually did not act as a conduit. For example, in a Danish case a private equity fund acquired a Danish holding company (Co2) through a holding company resident of Luxembourg (Co1). Co2 distributed dividends to Co1; on the same date Co1 extended loans to $\mathrm{Co} 2$ of the same amount as the distributed dividends. Danish tax authorities took the position that the dividends payment was subject to withholding tax, claiming that Co1 was not the beneficial owner of the dividends because it had no real power to act regarding the disposition of the dividends. The Court held that Co1 was not as a conduit company in respect of the dividends (and thus Co1 was the beneficial owner of the dividends) because it had not redistributed dividends, but rather lent an equal amount of money to its subsidiary Co2. The Court referred to the Commentary to Art. 10 and to the Report 'Double Taxation Convention and the Use of Conduit Companies' where it is stated that a conduit company could only be disregarded as the beneficial owner of dividends if the parent company had more power to act than normally granted to parent companies in international groups. The Court clarified that narrow powers to act were not in themselves sufficient for a company to be disregarded as the beneficial owner of the dividends. ${ }^{56}$

In a similar Czech case, Co1, a UK company held shares in Co2, a Czech company and transferred its shares to HoldCo, a Dutch company which became a UK tax resident. Czech tax authorities, relying on the substanceover-form rule, claimed that HoldCo was established solely for the purpose of avoiding withholding tax on dividends. The Court held that the fact that the dividends were actually paid did not automatically imply that HoldCo was not the beneficial owner of the shares because it is possible for a beneficial owner to instruct the paying agent to pay out the dividends to a third party. The fact that the dividends were paid to a third party did not automatically imply that HoldCo2 would not enjoy the income. ${ }^{57}$

55 Commentary to Art. $10 \S 12.6$.

56 Denmark, Østre Landsret (High Court of Eastern Denmark), B-2152-10, 20 December 2011, skat.Denmark/SKAT.aspx?oID=2035604; Denmark, Landsskatteretten (National Tax Tribunal), 09-01478, 3 March 2010, skat.Denmark/skat.aspx?oId=1896443\&vId=0.

57 Czech Republic, Nejvyšší Správní Soud (Supreme Administrative Court), 2 Afs 86/2010-141, 10 June 2011, nssoud.cz/files/SOUDNI_VYKON/2010/0086_2Afs_100_20110614100251_prevedeno.pdf 
1.70 By contrast, the same indicators are often used to characterize an intermediary entity as a conduit. For example, in a situation similar to the previous case, involving the payment of dividends by Co1 to the ultimate US parent company through intermediate holding companies, one of which was resident of Bermuda ( $\mathrm{HCn}$ ), a Czech Court held that $\mathrm{HCn}$ was not the beneficial owner of dividends distributed by $\mathrm{Co} 1$ under the treaty by referring to the Commentary to Art. 10, arguing that $\mathrm{HCn}$ was merely a conduit company as all the dividends were redistributed to another holding company in the line. ${ }^{58}$

1.71 National Courts have applied the indicators of the Commentary to determine whether intermediary entities are actually beneficial owners. Certain cases positively indicate the requirements for such entities to be considered as such, so that the treaty between the $\mathrm{SC}$ of the dividends and the $\mathrm{RC}$ of the beneficial owner can be applied. For example, a German case focused on a typical multi-layer holding structure: ParCo, resident of Bermuda owned Holdco resident of the Netherlands Antilles which in turn owned two companies resident of the Netherlands (DutchCos), which received dividends from two companies resident of Germany. German tax authorities denied the treaty reduced withholding tax on the basis of domestic laws. The Court remitted the case to lower Courts but listed the factors that indicate that a recipient is a beneficial owner in the following: business reasons for the interposition of the intermediary companies, e.g. limitation of liability; the holding of participations is part of a group long-term policy; and there are active companies in the ultimate $\mathrm{SC}$ of dividends. ${ }^{59}$

1.72 In a series of Swiss cases concerning complex securities transactions Courts have analysed whether the fact that a recipient of dividends has an obligation to pass on the dividends to a third party may lead to the conclusion that such a recipient is still the beneficial owner, i.e. the person has a broad discretion to decide how dividends are utilized. Courts examined to what extent this (possible) obligation was contingent on receiving the respective dividends. In a case concerning so-called 'total return swaps' Co1, a Danish subsidiary of an international group, traded futures and purchased shares to hedge the risk of these futures. When the futures matured Co1 would either sell the shares and close its portfolio or keep them and extend the futures contracts for another three months. In a few cases, Co1 would even hold the underlying assets for a longer period. However $\mathrm{Co} 1$ had neither concluded agreements about price risk and dividends with the counterparties of the futures nor bought any shares

58 Denmark, Landsskatteretten (National Tax Tribunal), 10-02772 / SKM No. 2012.26, 16 December 2011, skat.Denmark/SKAT.aspx?oId=1981807\&vId=0.

59 Germany, Bundesfinanzhof (Federal Fiscal Court), I R 74, 88/04, 31 May 2005, Bundessteuerblatt, 2006, II, 118. 
from them. Dividends received during the holding period of the assets were subject to a 35 per cent Swiss withholding tax, for which a full refund was claimed by Co1 under the Switzerland-Denmark treaty.

Swiss tax authorities claimed that Co1 was not the beneficial owner of the shares because only a minor part of the dividends remained with Co1. The Court held that, although Co1 had a financial duty towards the counterparty of a future, the contract did not include any obligation for Co1 to hedge its position with the acquisition of the underlying shares. The Court also held that there was no factual obligation on Co1 to transfer dividends: even if the acquisition of the underlying assets was partly funded by another company of the group, Co1 was not obliged to pass on the dividends to that company to repay the interest on the debt, since the interest payments were due irrespective of whether Co1 had effectively received a dividend. Hence the Court determined that the fact that $\mathrm{CO} 1$ was bearing the interest rate risk and the financing risk of the assets played a crucial role in indicating that the recipient of the dividends was actually the beneficial ownership thereof. ${ }^{60}$

In a Dutch case concerning dividends coupons UKCo, a UK resident company, bought dividends coupons (but not the underlying shares) of a Dutch company after the dividends had been declared but before they had been made payable. After the dividends had been made payable, UKCo received the dividends and claimed the reduced withholding of the relevant treaty. The Court held that UKCo after buying the purchase coupons had to transfer them together with their proceeds and therefore that UKCo had not acted as an agent or nominee for other persons thereby being beneficial owner of the dividends. ${ }^{61}$ But compare this case with a French case in which UKCo resident of the UK acquired dividend coupons - under a usufruct agreement with USco, a US company - of dividends distributed by the FrCo, resident of France and controlled by USco. In that case the Court held that the reduced withholding tax and transfer of the avoir fiscal of the France-UK treaty, could only be granted to USco (i.e. effective beneficial owner of the dividends), clarifying that UKCo was not entitled to the reduced treaty rate and transfer of the avoir fiscal imputation credit. The Court held that the usufruct was exclusively motivated by tax reasons, with the sole aim of benefiting from the

60 Switzerland, Bundesverwaltungsgericht (Federal Administrative Court), A-6537/2010, 7 March 2012, bvger.ch/publiws/pub/cache.jsf?displayName=A-6537/2010\&decisionDate=2012-03-07; Switzerland, Bundesgericht/Tribunal fédéral (Federal Supreme Court), A-1246/2011, 23 July 2012, bvger.ch/publiws/ download;jsessionid=5236F860A4EAEFE0B7AD33A777804372? decisionId=8a35f1a9-1283-4b94-9b51 $-423 \mathrm{e} 2 \mathrm{~d} 66 \mathrm{bea} 7$.

61 Netherlands, Hoge Raad der Nederlanden (The Netherlands Supreme Court), 28.638, 6 April 1994, Beslissingen Nederlandse Belasting Rechtspraak, 1994, 217c*. 
transfer of the avoir fiscal, which was available under the France-UK treaty and not under the France-US treaty: the concealed loan between UKCo and the USco was effectively reimbursed by FrCo and in practice USco delegated to FrCo the repayment of the loan contracted with the UKCo. ${ }^{62}$

1.75 By contrast, in various cases national Courts have identified situations in which a direct recipient of dividends cannot be deemed to also be the beneficial owner, so that the treaty between the $\mathrm{SC}$ of the dividends and the $\mathrm{RC}$ of the beneficial owner was applied. For example, in a case decided in the Netherlands, CanCo, a company resident of Canada owned 100 per cent of the shares of DutchCo which in year- 2 converted its shares into 10 per cent preferred shares and issued new ordinary shares to Co1 resident of the Netherlands Antilles owned for 60 per cent by CanCo company and for 40 per cent by Co3 resident of Panama. Thereafter DutchCo distributed retained profits of year-1 as dividends to be made available after 15 December of year-2. The dividends were eventually paid at the end of year-2 and Co1 claimed the reduced withholding tax under the relevant articles of the treaty between the Netherlands, Aruba and the Netherlands Antilles. The Court held that CanCo had retained its interest in the dividends through its participation in Co1 and other arrangements with Co2. Thus, Co1 was just a conduit in the flow of dividends eventually received by CanCo which only had that role to avoid Dutch taxes. ${ }^{63}$

1.76 A similar conclusion can be reached by looking at the business activity of the direct recipient of the dividends. For example, $\mathrm{X}$, resident of Germany, took shares in Co1, a company resident of Germany. $\mathrm{X}$ received dividends and claimed to apply the reduced treaty withholding tax on dividends, arguing that Co1 was resident of Switzerland because it was a Swiss company. German tax authorities asked Co1 to disclose information about its business activity but Co1 did not comply. The Court held that Co1 was established only for tax reasons as it only held capital without having its own office or its own personnel and consequently the establishment amounted to an abuse of law under German domestic law. ${ }^{64}$

\section{(ii) Abuse of the reduced treaty withholding taxes for outbound dividends}

1.77 Source countries of dividends can react to the abuse of their treaties when reduced withholding taxes on outbound dividends are improperly avoided (see infra at paras 6.06-6.10 and 6.57) by relying on broad domestic anti-abuse

62 France, Conseil d'État (Supreme Administrative Court), 283314, 29 December 2006, Droit fiscal 2007, 87.

63 Netherlands, Hoge Raad der Nederlanden (The Netherlands Supreme Court), 25.451, 28 June 1989, Beslissingen Nederlandse Belasting Rechtspraak, 1990, 45c*.

64 Germany, Bundesfinanzhof (Federal Fiscal Court), I R 234/73, 21 January 1976, Bundessteuerblatt, 1976, II, $15,513$. 
rules. For example, in a Swiss case the Court held that Switzerland had the power unilaterally to adopt anti-abuse measures designed to prevent residents of third countries from taking benefit from Swiss treaties to which they were not entitled. ${ }^{65}$ The Commentary specifies that even if the recipient of dividends is the beneficial owner anti-abuse rules may still apply.

Good examples of abusive transactions in this area are offered by a line of cases decided in Switzerland, a country that has introduced ad hoc rules in its treaties to contrast abuse regarding domiciliary companies. For example, a case focused on the following fact pattern: HolCo was established in the Netherlands shortly after SwissCo was established in Switzerland. In year-3 dividends were paid by SwissCo to HolCo, on which 35 per cent of tax was withheld in Switzerland. HolCo used the amount received to repay an intra-group loan it had received to finance the acquisition of SwissCo and claimed the application of the reduced treaty withholding tax, which was rejected by tax authorities. The Court denied the application of the treaty withholding tax because HolCo was a 'domiciliary company', on the basis of circumstances indicating that the main reason for establishing the relation between SwissCo and HolCo had been to benefit from the reduced withholding treaty rate. ${ }^{66}$

In a similar Austrian case SwissCo, a company resident of Switzerland, was subjected to Austrian withholding tax at 25 per cent in respect of dividends received on a holding in $\mathrm{AuCo}$, a company resident of Austria, but claimed the application of the reduced treaty withholding tax. This was refused by Austrian tax authorities. The Court in Austria held that SwissCo was a domiciliary company whose only activity was holding shares in AuCo. Furthermore in light of the fact that the certificate obtained from Swiss tax authorities did not disclose either SwissCo's shareholders or the beneficial owners of the dividend, Austria had the power to apply its domestic laws to prevent SwissCo benefiting from the treaty. ${ }^{67}$

65 Switzerland, Commission fédérale de recours en matière de contributions (Federal Tax Appeal Commission), VPB 65.86, 28 February 2001, Steuerrevue, 2002, 30.

66 Switzerland, Bundesgericht/Tribunal fédéral (Federal Supreme Court), A 30/83, 9 November 1984, Archiv für Schweizerisches Abgaberecht, 1985, 54, 1-2, 64. On a case about abuse of treaties on inbound dividends see: Argentina, Tribunal Fiscal de la Nación (Federal Tax Court), Molinos Rio de la Plata S.A., 14 August 2013, La Leyonline AR/JUR/60751/2013.

67 Austria, Verwaltungsgerichtshof (Supreme Administrative Court), 97/14/0070, 26 July 2000, Österreichischen Steuerzeitung, 2001, 57. 
1.80 Another type of base company which are not the beneficial owners are companies that accumulate undistributed profits. A similar approach is found in the subject-to-tax approach suggested by the Commentary (see supra at paras 1.46-1.47).

For example, a Swiss case has in practice applied a guideline provided by the Commentary according to which if the beneficial owner of dividends arising in the $\mathrm{SC}$ is a company resident of the $\mathrm{RC}$ and all or part of its capital is held by shareholders who are not resident of the SC and the company does not distribute dividends and enjoys preferential tax regime, then it may be justifiable to deny in the SC of dividends the reduced treaty. SwissCo's policy was one of not distributing the foreign-source income to its shareholders abroad. The Court held that the requirements of these anti-abuse domestic rules were met by SwissCo.

1.81 Two individuals $\mathrm{X}$ and $\mathrm{Y}$, resident of Germany, owned shares in SwissCo, a company resident of Switzerland. SwissCo sold an asset and used the proceeds to extend a loan to $\mathrm{X}$ and $\mathrm{Y}$, who eventually sold their shares in Swiss Co to SwissCo1 and 2, two companies resident of Switzerland who paid part of the price in cash and for the balance took over the debt $\mathrm{X}$ and $\mathrm{Y}$ had with SwissCo. Thereafter SwissCo distributed dividends which SwissCo1 and 2 used to repay the debt. Since SwissCo1 and 2 were corporate entities and each owned more than 20 per cent of the shares of SwissCo, the dividends they received were exempt from the corporation income tax and were not subject to withholding tax. The issue was whether this amounted to tax avoidance. The Court confirmed the 35 per cent withholding arguing that the treaty could not be applied because the transaction constituted an abuse. ${ }^{68}$

1.82 Another type of abusive structure is one based on non-active companies. For example, $\mathrm{X}$, an individual resident of Bermuda, wholly owned a Bermudan company, which owned a company in Guernsey, which owned DkCo, a company resident of Denmark, which held 100 per cent of a SwissCo, a company resident of Switzerland. SwissCo distributed dividends to DkCo but claimed not to apply the withholding tax in Switzerland on the basis of the dividends article of the Switzerland-Denmark treaty, according to which the right to tax dividends was exclusively attributed to Denmark. Swiss tax authorities refused to reimburse the withholding tax arguing that $\mathrm{DkCo}$ did not carry out any activities in Denmark and that its only purpose was to demand the application of the zero rate for participation dividends under the

68 Switzerland, Bundesgericht/Tribunal fédéral (Federal Supreme Court), A.87/1980, 1 December 1981, Archiv für Schweizerisches Abgaberecht, 1982, 50, 10, 583. 
treaty. The Court confirmed that $\mathrm{DkCo}$ was not engaged in an active trade or business in Denmark and that the ultimate shareholder $\mathrm{X}$ was responsible for all the commercial management functions with the result that a taxpayer who was resident of neither Denmark and Switzerland was taking undue advantage of the Denmark-Switzerland treaty. ${ }^{69} \mathrm{~A}$ similar approach is found in the bona fide safeguard clauses suggested by the Commentary (see supra at paras 1.49-1.51).

In other cases Courts have identified context-related situations of abuse. For example, in another Swiss case, USco, a company resident of the US, fully owned HoldCo1 and HoldCo2, both resident of the US, which respectively (60 and 40 per cent) owned Co1, a company resident of Switzerland. In year-1 Co1 distributed dividends and in year- 4 the shares of $\mathrm{Co} 1$ were transferred from HoldCo1 and HoldCo2 to USco, a company resident in the US. In year-2 Co1 claimed the application of the reduced treaty withholding tax with regard to dividends distributed in years-2-4 on the grounds that more than 95 per cent was indirectly controlled by USco. The issue was whether the reduced withholding tax rate of 5 per cent, which applied where a company controlled, directly or indirectly, at least 95 per cent of the voting power in the company paying the dividends, was also applicable to distributions made to two companies, which themselves were fully controlled by the same holding company. The Court found that a parent-subsidiary relationship was not present in the case at hand because Co1 was controlled through interposed companies (HoldCo1 and HoldCo2) which themselves were not in a direct parent-subsidiary relationship, and therefore held that the transfer of shares had taken place primarily with the intention of securing the application of the reduced withholding tax rate.

Finally, other cases focus on parent-subsidiary structures devised to abuse the EU Parent-Subsidiary Directive to extract dividends from the EU avoiding withholding taxes provided for by treaties between EU Member States and non-EU countries. For example, in a Spanish case UKPar, a company resident of the UK, had 100 per cent control of SpSub, a company resident of Spain. UKPar was held by $\mathrm{X}$ an individual resident of the United Arab Emirates (UAE). SpSub distributed dividends to UKPar, and UKPar then distributed dividends of a similar amount to $\mathrm{X}$. Tax authorities in Spain rejected the application of the Parent-Subsidiary Directive to the dividend distribution by the SpSub on the basis of a domestic anti-abuse clause. So the issue was

69 Switzerland, Bundesgericht/Tribunal fédéral (Federal Supreme Court), 2A.239/2005, 28 November 2005, Revue de droit administratif et fiscal, 2006, II, 239. 
whether the zero rate under the Parent-Subsidiary Directive was applicable to the dividends distributed by the SpSub to its UKPar.

1.85 The Court held that the exemption for dividends distributed by SpSub to UKPar was not available because (according to the domestic anti-abuse rule) the majority of the voting rights of UKPar were held by $\mathrm{X}$, a resident of a third country. Moreover the exceptions to the application of domestic anti-abuse rules could not operate because UKPar was not effectively conducting a business directly linked with the activity carried out by SpSub; UKPar did not manage SpSub and did not use substantial human and material resources in order to do so; and evidence had not been provided that UKPar company was incorporated for sound economic reasons and not merely to benefit from the Parent-Subsidiary withholding tax/participation exemption..$^{70}$ The same decision was reached in a similar case in which a US company owned, through two intermediate Dutch companies, a Spanish subsidiary which distributed dividends free of Spanish withholding tax to the Netherlands, and then from the Netherlands companies to the US parent. The Court held that the Netherlands parent of SpSub was a conduit company. ${ }^{71}$

1.86 But compare these cases with a case decided in Germany in which $\mathrm{X}$ an individual citizen of Monaco, was the shareholder of SwissCo, a company resident of Switzerland that held shares in GerCo, a company resident of Germany. SwissCo claimed the reduction in the German withholding tax on the dividends received from the German company under the relevant article of the Germany-Switzerland treaty. The issue was whether SwissCo (the shares of which were held by $\mathrm{X}$ a resident of Monaco) was entitled to the reduction of the withholding tax on dividends received from the GerCo. The Court held that the German domestic anti-abuse provision did not apply to non-resident companies with non-resident shareholders and consequently, the taxpayer was entitled to the reduction of the withholding tax on the dividends. ${ }^{72}$

1.87 Case law concerning the abuse of the reduced withholding treaty rate also provides indicators of genuine transactions. For example, a German case analysed a so-called 'multiple intermediary companies structure' reaching the conclusion that there was no abuse of German laws. UKCo, a company

70 Spain, Tribunal Económico Administrativo Central (Administrative Court), RG 1481/2007, 28 September 2009, serviciostelematicos.minhap.gob.es/DYCteac/criterio.aspx?id=00/01481/2007/00/0/1\&q=s\%3d1\%2 6rn\%3d01481\%26ra\%3d2007\%26fd\%3d\%26fh\%3d\%26u\%3d06\%26n\%3d\%26p\%3d\%26c1\%3d\%26c2\%3d\% 26c3\%3d\%26tc\%3d1\%26tr\%3d\%26tp\%3d\%26tf\%3d\%26c\%3d0\%26pg\%3d.

71 Spain, Audiencia Nacional (National Court), 59/2005, 22 January 2009, audiencia-nacional.vlex.es/vid/is-4rgit-benicarlo-52046115.

72 Germany, Bundesfinanzhof (Federal Fiscal Court), IR 89/80, 29 October 1981, Federal Tax Gazette, 1982, II, 150. 
resident of the UK, directly held 20 per cent of the stock in Ger1, a corporation resident of Germany. In year-1 UKCo transferred its 20 per cent participation in Ger1 to UKCo2, a company resident of the UK. As a result, UKCo2, owned 20 per cent of the stock, and four other UK companies (UK1-4) each held 20 per cent of the remaining stock of Ger1. The five UK companies were ultimately - partly through other intermediary companies fully owned by UKCo. Ger1 distributed dividends to UKCo2, and claimed a reduced German-UK treaty withholding tax which was refused by German tax authorities on the basis of domestic laws according to which dividends distributed by a Germany company to non-resident recipients were subject to a higher 25 per cent withholding tax.

Tax authorities argued that the recipient company owned indirectly at least 25 per cent of the stock of the distributing company, because the participations in the UK1-4 companies in Ger1 were also indirectly owned by UKCo2. As the concept of 'indirectly ownership' was not defined in the treaty the Court held that these terms should have the meaning which they have under German domestic laws, unless the context requires otherwise. The Court determined that the term 'indirectly owned', on the basis of its ordinary meaning, referred to a group of associated companies as a whole which group included the recipient of the dividends and the other UK companies which directly held shares in Ger1. ${ }^{73}$

Another case law indicator of non-abusive structure in respect of the reduced treaty withholding tax rate is the fact that the direct recipient of dividends, within the structure of a group, is an active holding. For example, in a German case, Co1, a company resident of Switzerland, was wholly owned by two related individuals, $\mathrm{H}$ and $\mathrm{W}$. Co1 managed participations in companies and traded securities and immovable property. Co1 received dividends from German-resident companies, which were subject to 25 per cent German dividends withholding tax. German tax authorities denied the treaty benefits arguing that this was a case of abuse of law under German domestic anti-abuse rules, according to which tax liability cannot be avoided or reduced through the misuse of civil legal forms. The Court held that when the recipient company has income-raising functions of its own there is no abuse. By contrast, abuse (and treaty shopping) occurs when active income-raising

73 Germany, Finanzgericht Nordrhein-Westfalen (Tax Court Nordrhein-Westfalen), VI 452/77 KE, 9 February 1989, Recht der Internationalen Wirtschaft, 1982, 292. 
activities of the company are secondary when compared to the company's passive income. ${ }^{74}$

\section{b. Beneficial owner of interest}

\section{(i) Indicators of beneficial ownership of interest developed by case law}

1.90 The concept of the beneficial owner of interest plays an important role in determining whether the reduced withholding tax can be actually applied under a bilateral treaty between the payer of interest and a direct recipient when interest received by that direct recipient is in turn paid to other recipients (see infra at paras 6.06-6.10 and 6.57).

1.91 The rationale of the beneficial owner concept is to prevent residents of third countries having access to the treaty benefits by ensuring that the recipient of the interest is also the beneficial owner of the interest. This rationale is evidenced in a case decided in Mexico, in which Mex-Co, a company resident of Mexico, received a loan from UK-Co1, a company resident of the UK, but the interest on the loan was paid to UK-Co2, a company also resident of the UK, appointed by UK-Co1 as a collecting agent. Mex-Co applied the reduced treaty withholding tax which was denied by tax authorities, arguing that UK-Co2 could not be regarded as the beneficial owner of the interest as there was no debt relation between Mex-Co and UK-Co2. The issue was whether the fact that the interest was paid to UK-Co1 precluded the application of the interest article of the Mexico-UK treaty on the basis of the beneficial ownership criterion.

1.92 The Court held that the reduced withholding treaty applied and stated that in interpreting and applying treaties tax authorities were bound by the Commentary to the basis of domestic laws and pointed out that the rationale of the beneficial ownership principle is to prevent residents of third countries having access to the treaty benefits. The Court thus determined that the denial of the treaty withholding tax was not based on such a principle because both the company from which the loan was obtained (UK-Co1) and the company to which the interest was paid (UK-Co2) were resident of the UK. So for the purposes of the interest article it was irrelevant which of the two UK companies was the beneficial owner of the interest. ${ }^{75}$

74 Germany, Bundesfinanzhof (Federal Fiscal Court), IR 201/82, 5 March 1986, Bundessteuerblatt, II, 1986, 496.

75 Mexico, Tribunal Fiscal de la Federación (Federal Tax Court), 100(20)33/97/20328/96, 24 February 1998, Revista del Tribunal Fiscal de la Federación, 1998, 303. 
On the basis of these guidelines national Courts have identified situations in 1.93 which interest is received by a genuine beneficial owner, as well as situations in which interest is received by a conduit which is not a beneficial owner.

\section{(ii) Interest received by beneficial owner and lack of conduit structures}

The approach used by national Courts is that a conduit company can only be disregarded as the beneficial owner of the interest if the interest is paid on the basis of a loan arrangement that is a back-to-back loan, or the interest is redistributed. This approach has been applied to revolving and converted loans, to consortium financing, and to financing situations that involve interposed partnerships or intermediary branches. In a Danish case concerning revolving and converted loans a private equity fund acquired DkTarget a company resident of Denmark through LuxCo, a company resident of Luxembourg. At the beginning of year-1 DkTarget distributed dividends to LuxCo and contextually LuxCo granted a convertible loan and an ordinary loan to DkTarget in the amount of the distributed dividends, which, at the end of year- 1 and in year- 2 were converted into shares of LuxCo in DkTarget (the value of conversion included accrued interest). The issue was whether LuxCo could be regarded as the beneficial owner of the interest received from DkTarget under the interest article of the treaty.

The Court held that LuxCo was the beneficial owner of interest paid by DkTarget because the interest was not repaid on the basis of a loan arrangement that could be regarded as a back-to-back loan but was converted into shares of DkTarget. ${ }^{76}$ In the same private equity structure of the previous case involving a LuxCo and a DkTarget, the DkTarget did not distribute dividends, and the Court held that LuxCo could not be regarded as a conduit in respect of interest (and was the beneficial owner thereof) because interest was not redistributed but converted into shares. ${ }^{77}$

A similar approach has been applied to consortium loans. IndoCo, a company resident of Indonesia operating in the offshore gas extraction, had three shareholders, among them MauCons, a consortium established and registered in Mauritius and held by several companies operating in the same industry of IndoCo, which paid interest to MauCons on a loan obtained from it. The issue was whether MauCons was the beneficial owner of the interest and was thus eligible for relief under the interest article of the treaty.

76 Denmark, Landsskatteretten (National Tax Tribunal), 09-01483, 1 November 2009, Tidsskrift for Skatter og Afgifter, 2010, 502.

77 Denmark, Landsskatteretten (National Tax Tribunal), SKM 2010.729 LSR, 17 November 2010, Tidsskrift for Skatter og Afgifter, 2010, 974. 
1.97 The Court referred to the sections on conduit company and beneficial owner of the Commentary to Art. 11 in which the beneficial ownership requirement refers to the person economically able to enjoy the interest and held that the $\mathrm{SC}$ of the interest should waive its right to impose tax pursuant to its domestic laws only if MauCons as the recipient of the interest income proved that it was the beneficial owner of the interest income because an economic or 'substance over form' approach should be taken in determining beneficial ownership. ${ }^{78}$

1.98 A similar situation is found in a case decided in Brazil where an intermediary branch, rather than a partnership, was used. SweCo, a company resident of Sweden, had a subsidiary, BrSub, a company resident of Brazil, which was financed by PanPE, the branch in Panama of JapCo, a company resident in Japan. Tax authorities in Brazil sought to apply the domestic withholding tax because there was no treaty between Brazil and Panama, while the BrazilJapan treaty did not apply to the transaction at hand. So the issue was whether the reduced withholding tax provided for by the interest article of the Brazil-Japan treaty applied to the interest paid by BrSub to PanPE. The Court held that there was no double taxation because the interest was not taxed either in Panama or in Japan and thus there was no need to consider the application of the Brazil-Japan treaty.79

\section{(iii) Interest received by a conduit which is not a beneficial owner}

1.99 Other Danish cases focused on a similar top-down group structure which however involved pass-through using the deduction of group contributions provided for by Danish domestic laws. For example, JerCo, a company resident of Jersey, acquired a company resident of Denmark (DkTarget) through two companies resident of Sweden (SweCo1 and SweCo2). SweCo1 was the parent company of SweCo2. Neither of the Swedish holding companies carried out real business activities except for the holding of the shares of SweCo2 and DkTarget respectively. On the day JerCo acquired SweCo1, JerCo granted a loan to SweCo1. Similarly, SweCo2 granted a loan to DkTarget on the day that it acquired DkTarget. Both loans had the same face values and interest rates. DkTarget paid interest to $\mathrm{SweCo}$, which the latter subsequently transferred to SweCo1 as group contribution. SweCo1 subsequently paid interest to JerCo. So the issue was whether, under the interest article of the Nordic Convention, SweCo2 and SweCo1 were the beneficial owners of the interest received from DkTarget.

78 Indonesia, Pengadilan Pajak (Tax Court), Put-13602/PP/M.I/13/2008 14 March 2008

79 Brazil, Superior Tribunal de Justiça (Superior Court of Justice), 457.228, 18 March 2004, stj.jusbrasil. com.Brazil/jurisprudencia/19502189/ recurso-especial-resp-457228-pr-2002-0088257-2/inteiro-teor19502190 . 
The Court referred to the Commentary to Art. 11 and held that neither

SweCo2 nor SweCo1 were the beneficial owners of the interest: the group contributions between SweCo2 and SweCo1 did not result in taxable income as they were deductible for both companies, which were, therefore, conduit companies in so far as they did not have real power of disposition of the interest. A similar method is found in the channel approach suggested by the Commentary (see supra at para 1.48). So DkTarget's interest liability was in fact passed on to JerCo through SweCo1 and SweCo2 (which had no business activities apart from the holding of the shares of DkTarget), and the same occurred with the loans. ${ }^{80}$ Another case had a similar fact pattern and was decided in the same way. ${ }^{81}$

Aiken, a case decided in the US, focuses on a similar back-to-back loan whose sole purpose was to obtain a zero treaty withholding under the relevant treaty. In year-1 US-Co, a company resident of the US, borrowed funds from $\mathrm{BahCo}$, a company resident of the Bahamas, in exchange for a promissory note, which in year- 1 assigned the US-Co note to a Honduras corporation (HondCo) in exchange for a series of notes with the same total amount and rate of interest. US-Co was notified of the assignment and made the payments due on its promissory note to HondCo. US-Co, BahCo, and HondCo were related parties and the effect of the assignment was to create a back-to-back loan whereby HondCo was interposed between US-Co and BahCo with respect to payments of interest and principal on the note. HondCo received the payments on the note from US-Co and thereafter made identical payments to BahCo. The US had a treaty in force with Honduras but not with the Bahamas. The issue was whether the interest were exempt from tax under Art. IX of the US-Honduras treaty.

The Court held that, in spite of the fact that HondCo was a person for the purposes of the treaty because it met the definition of a Honduran corporation as given in the relevant article of the treaty, interest had not been effectively 'received by' HondCo as required by the interest article. The Court added that the term 'received by' was not defined in the treaty and therefore the US was allowed to interpret the term under US domestic laws, i.e. interest must be received free of an obligation to transfer them to another person. The term 'received by' refers to complete dominion and control over the funds, and not just to the obtaining of physical possession on a temporary basis of interest. As HondCo was required to pay to BahCo the same amount that it collected from US-Co,

80 Denmark, Landsskatteretten (National Tax Tribunal), 09-00064 / SKM No. 2011.57, 22 December 2010, skat.Denmark/SKAT.aspx?oID=1924630\&chk=211047.

81 Denmark, Landsskatteretten (National Tax Tribunal), 09-03189 / SKM No. 2011.485, 25 May 2011, skat.Denmark/SKAT.aspx?oId=1950070\&vId=0. 
the Court concluded that the transaction had no valid or economic business purpose apart from obtaining the exemption from withholding under the US-Honduras treaty. The Court determined that HondCo was a collection agent with respect to interest received from US-Co and was a conduit for interest between US-Co and $\mathrm{BahCo}$, so it had no actual beneficial interest in the interest it received. The Court also found that this holding was supported by the fact that US-Co had misled US tax authorities by not fully disclosing the transfer of the loan from BahCo to HondCo. ${ }^{82}$

1.103 In a private equity financing structure a venture capital fund (JerFund) domiciled in Jersey acquired in year-1 DkTarget, a company resident of Denmark through DkNewCo, another company resident of Denmark. The residual share capital was owned by DkFund, a Danish fund. DkNewCo's acquisition was financed by means of loans: in year- 1 JerFund granted a loan to DkNewCo and assigned its claim against DkNewCo to LuxNewCo, a company resident of Luxembourg. LuxNewCo thereafter acquired the participation of JerFund in $\mathrm{DkNewCo}$, and paid the price by using a loan received from JerFund. In year-2 the amount of the shareholder loan totalled the equivalent of the debt between LuxNewCo and $\mathrm{DkNewCo}_{0}$. In year-3, DkNewCo repaid the loan (principal and interest) to LuxNewCo, which immediately thereafter repaid the loan (principal and interest) to JerFund.

1.104 The issue was whether LuxNewCo was the beneficial owner of the interest and therefore had a right to the zero withholding tax under the interest article of the treaty. The Court referred to the Commentary to Art. 11 and held that LuxNewCo was a conduit company with no actual power or authority to decide on the disposal of the funds received because, from a substantial standpoint, it did not retain any amount of the upward flow of interest arising from the revolving loan, and as a result LuxNewCo was not the beneficial owner of the interest received in accordance with the treaty. ${ }^{83}$

1.105 Anti-abuse approaches have been used in the US in respect of these financing structures. For example, in Guangdong the US substance over form doctrine was applied to a financing structure that used a Hong Kong intermediary company. The government of the Chinese province of Guangdong wholly-owned ChinaCo1, a company resident of China which in turn owned 100 per cent of ChinaCo2, a company established in Hong Kong, and 50 per cent of US-Co, a company resident of the US. ChinaCo1 and ChinaCo2 shared office space in

82 United States, US Tax Court, Aiken Industries, Inc. v. Commissioner of Internal Revenue, 5 August 1971, 56 T.C. 925.

83 Denmark, Landsskatteretten (National Tax Tribunal), 11-00210 / SKM2012.409LSR, 31 January 2012, skat.Denmark/SKAT.aspx?oId=2062841\&vId=0. 
Hong Kong and made loans to US-Co which paid interest on the loans to ChinaCo1 and ChinaCo2. US-Co's position was that the loan to US-Co was in substance a loan from ChinaCo1 because ChinaCo2 only acted as an agent or conduit for ChinaCo1 which was a resident of China (rather than Hong Kong), and thus could claim benefits under the US-China treaty. US-Co therefore did not collect US withholding tax on the basis that the interest was exempt from withholding under the interest article of the US-China treaty, which provided an exemption for interest paid to financial institutions (such as ChinaCo1) wholly-owned by the Chinese government. A similar approach is found in the bona fide safeguard clauses suggested by the Commentary (see supra at paras 1.49-1.51).

The issue therefore was whether interest paid by US-Co to ChinaCo2 (a 1.106 company resident of Hong Kong and indirectly owned by a provincial government of China) was exempt from withholding tax under the interest article of the US-China income treaty. The Court determined that the loan was not in substance extended from ChinaCo1 and that ChinaCo2 was not acting as the agent of ChinaCo1 in the loan to US-Co and therefore interest paid by US-Co to ChinaCo2 was not exempt from withholding tax because ChinaCo2, a company resident of Hong Kong, was not entitled to the benefits of the interest article of the US-China treaty. ${ }^{84}$

In Del Commercial the step transaction doctrine has been used. US-Co, a company resident of the US, received intra-group financing. The funds were initially borrowed from CanBank, a company resident of Canada, and were routed through companies of the group. The companies participating in the transaction were CanCo and $\mathrm{CanCo2}$, CayCo, AntCo, and NethCo respectively residents of Canada, the Cayman Islands, the Netherlands Antilles, and the Netherlands. US-Co borrowed funds from NethCo through a Barbados office. The issue was whether the interest paid by US-Co on the loan was exempt from US withholding under the interest article of the US-Netherlands treaty or were subject to withholding tax under the interest article of the US-Canada treaty. The Court held that payments made to NethCo were in substance made to CanCo to avoid US taxes as they were unjustifiably subjected to the zero withholding tax of the US-Netherlands treaty, while the applicable treaty was the US-Canada treaty which imposed a withholding tax. US-Co made the repayments on the loan directly to CanCo, and although NethCo recorded these payments on its books, US-Co did not make the payments to NethCo so the US-Netherlands treaty could not apply to a

84 United States, US Court of Appeals for the Fifth Circuit, New York Guangdong Finance Inc v. Commission of Internal Revenue, 20 November 2009, ustaxcourt.gov/InOpHistoric/newyorkguangdong.TCM.WPD.pdf. 
transaction directly between US-Co and a CanCo, and therefore US-Co should have collected US withholding tax on these payments. The Court in reaching this conclusion applied the step-transaction doctrine and noted that for US-Co to enjoy the benefits of the US-Netherlands treaty, the transaction must have had a sufficient business or economic purpose. Since the sole purpose of the transaction with NethCo was to avoid US taxes imposed via the US-Canada treaty, the formal recourse to the US-Netherlands treaty could not shield US-Co from the application of the step-transaction doctrine. ${ }^{85}$

1.108 Finally Indofood, ${ }^{86}$ a case, decided in the UK, provided further substantial elements to determine beneficial ownership of interest. ${ }^{87}$ Indo-Co, a company resident in Indonesia obtained a loan from a group of syndicated lenders in the UK. UK-Bank, a bank resident in the UK, was the trustee and collecting agent of the syndicated lenders. Indo-Co established a subsidiary Maur-Co, a company resident in Mauritius, which obtained the loan by issuing notes to the lenders and then forwarded the sum by means of a loan of identical amount to Indo-Co, which paid interest to Maur-Co. Interest in the same amount was paid by Maur-Co to lenders a few days after interest had been paid by Indo-Co to Maur-Co. Indo-Co guaranteed the repayment of the notes. The result was that Indo-Co took advantage of the Indonesia-Mauritius treaty which provided a 10 per cent withholding tax (instead of the 20 per cent withholding tax on interest which would have been paid by Indo-Co to UK-Bank under the Indonesia-UK treaty). In 2005 the Indonesia-Mauritius treaty expired and as a result the Indonesian 20 per cent withholding tax would have applied. A litigation therefore arose about whether a Neth-Co, a hypothetical Dutch interposed company in a re-arranged loan structure, could qualify as the beneficial owner of interest paid out from Indonesia, in which case Indo-Co would not be entitled to terminate the loan agreement. On the basis of an arbitration clause of the loan agreement the case was brought in front of an English court, which denied that Neth-Co would be beneficial owner of interest and therefore that Indo-Co was entitled to early terminate the loan agreement. The Court relied on the Commentary and held that the

85 United States, US Tax Court, Del Commercial Properties, Inc. v. Commissioner of Internal Revenue, 20 December 1999, 78 T.C.M. (CCH) 1183.

86 United Kingdom, High Court of England and Wales, Indofood International Finance Ltd v. JPMorgan Chase Bank NA, London Branch, [2006] STC 192, (2005) 8 ITLR 236.

87 See Philip Baker, 'United Kingdom: Indofood International Finance Ltd v. JP Morgan Chase Bank NA' in: Michael Lang et al., eds., Beneficial Ownership: Recent Trends (IBFD, Amsterdam 2013, p. 27 et seq; Robert J. Danon, 'Interest (Article 11 OECD Model Convention)' in: Michael Lang et al., eds., Source versus Residence. Problems Arising from the Allocation of Taxing Rights in Tax Treaty Law and Possible Alternatives (Kluwer Law International, Alphen aan den Rjin 2008, p. 100 and J. David B. Oliver and Ross Fraser, 'Beneficial ownership: HMRC's draft guidance on interpretation of the Indofood decision', British Tax Review 1 (2007), 39. 
concept of beneficial ownership is incompatible with that of the formal owner who does not have the full privilege to directly benefit from the income, a reference to a circular letter issued by the Indonesian tax authorities in 2005. Moreover the Court adopted a substantial approach and noted that the interposed company had no possibility to utilize interest received for any purpose other than to forward it to the lenders and, moreover, that it could not raise interest from any other source. Accordingly, Indo-Co guaranteed on behalf of the Maur-Co the repayment of the notes.

\section{c. Beneficial owner of royalties}

\section{(i) Indicators of beneficial ownership of royalties developed by case law}

Art. $12 \S 1$ provides that royalties arising in the SC shall be taxable only in the $\mathrm{RC}$ if they are beneficially owned by a resident of the $\mathrm{RC}$. So if royalties are not beneficially owned by a resident of the $\mathrm{RC}$, then other articles of the treaty become applicable allowing taxation in the $\mathrm{SC}$, in particular the business profits article (see infra at paras 7.04-7.153), or there can be imposition of withholding taxes (see infra at para 7.13). The concept of the beneficial owner of royalties thus plays an important role in determining whether taxation in the $\mathrm{SC}$ is allowed under a bilateral treaty between the payer of royalties and a direct recipient when royalties received by that direct recipient are in turn paid to other recipients.

\section{(ii) Royalties received by beneficial owner and lack of conduit structures}

The approach used by national Courts to determine whether the recipient of royalties is also the beneficial owner is to look at the contextual legal arrangements. An important case setting criteria to identify the beneficial owner of royalties is Velcro decided in Canada. Can-Co, a company resident of Canada, entered into a license agreement with Neth-Co, a company resident of the Netherlands, for the right to use intellectual property belonging to Neth-Co in exchange for a royalty.

Can-Co withheld Canadian tax at the applicable rate under the CanadaNetherlands treaty. Neth-Co subsequently became a resident of the Netherlands Antilles, a country that had no income treaty with Canada, and assigned its rights and obligations under the license agreement to Neth-Sub, a subsidiary resident of the Netherlands, but the contractual ownership of the intellectual property originally licensed to Can-Co remained with Neth-Co. As a result Can-Co paid all the royalties under the assigned license agreement to Neth-Sub, which in turn paid 90 per cent of them to Neth-Co within 30 days of receipt. 
1.111 The issue was whether Neth-Sub was the beneficial owner of royalties paid to it by Can-Co under the royalties article of the Canada-Netherlands treaty, in spite of the fact that Neth-Sub had an obligation to pay 90 per cent of the royalties received from Can-Co to Neth-Co in the Netherlands Antilles. The Court applied the test set out in Prévost to determine whether Neth-Sub was the beneficial owner of the royalties ${ }^{88}$ and established four requirements of beneficial ownership (possession, use, risk, and control); these were met by Neth-Sub which therefore was the beneficial owner of the royalties. Most importantly the funds paid as royalties were deposited in an account over which Neth-Sub had exclusive possession and control and were mixed with other Neth-Sub accounts. Moreover, Neth-Sub bore the currency risk and was not subject to instructions in dealing with the funds, the funds earned interest belonging to Neth-Sub, and the amount of the royalty payments received from Neth-Sub differed from the amount paid by Neth-Sub to Neth-Co. ${ }^{89} \mathrm{~A}$ similar method is found in the channel approach by the Commentary (see supra at para 1.48).

1.112 An entity interposed in the flow of royalties and receiving a collection or handling fee has not been deemed to be a mere conduit. In a French case, Nontr-Co, a company established in a non-treaty country, had sub-licensed the right to use the name of a famous sportsman to Neth-Co, a company resident of the Netherlands, that belonged to a group of companies controlled by a Dutch bank. Nontr-Co had the power to approve in advance any licensing contract to be entered into by Neth-Co with third parties and to almost 100 per cent of the payments received by Neth-Co from those third parties. Thereafter Neth-Co entered into a contract allowing Ger-Co, a company resident of Germany that produced sports equipment, to use the name of the famous sportsman to promote its products. Ger-Co made payments to Neth-Co, which in turn transferred almost 100 per cent of those payments to Nontr-Co.

1.113 The Court held that the royalties article of the Germany-Netherlands treaty (which provided the exemption in the SC of outbound royalties) did not apply to payments made by Neth-Co to Nontr-Co. The Court noted that income received by Neth-Co was a collection or handling fee (not royalties) because 95-98 per cent of the receipts of Neth-Co had to be passed on to Nontr-Co,

88 Canada, Tax Court of Canada, Prévost Car Inc. v. Her Majesty the Queen, 22 April 2008, 2008 TCC 231.

89 Canada, Tax Court of Canada, Velcro Canada v. The Queen, 24 February 2012, 2012 TCC 57. 
and Neth-Co was used primarily for the independent financial services, and not for marketing the name of sportsmen. ${ }^{90}$

The effective taxation of royalties in the hands of the recipient partners of a partnership resident of the same country of the partnership is similarly an indicator that the partnership is not a conduit. For example, in another French case, French-Co, a company resident of France, was engaged in the rental of computer equipment to French clients. French-Co bought equipment and sold it to Neth-Co, a company resident of the Netherlands, which rented back the equipment to French-Co which, in turn, rented it to its French clients. French-Co paid royalties to Neth-Co for the use of the computer equipment but French tax authorities denied that Neth-Co effectively received any royalties beccause Neth-Co had neither its activity nor its effective place of management in the Netherlands, and paid an amount equal to 68 per cent of the French-source royalties to Swiss-Co, an affiliated company resident of Switzerland.

So the issue was whether Neth-Co could be considered to be the beneficial owner of royalty payments under the royalties article of the FranceNetherlands treaty that did not explicitly refer to the beneficial ownership requirement. The Court held that the royalties article of the FranceNetherlands treaty could be applied to the royalties paid by French-Co to Neth-Co because although Neth-Co could not be considered to be a Netherlands resident as it was transparent for tax purposes, the partners of Neth-Co, resident of the Netherlands, were also the beneficial owners of the royalties paid by French-Co. The Court also held that tax authorities had not proved that the amount of royalties paid by French-Co to Swiss-Co was abnormally high given its services provided to Neth-Co.

\section{(iii) Royalties received by a conduit which is not a beneficial owner}

National Courts have identified situations in which royalties are received by a conduit which is not a beneficial owner, particularly when there is no effective taxation of royalties in the hands of the recipient partners of a partnership. A similar method is found in the subject-to-tax approach suggested by the Commentary (see supra at paras 1.46-1.47). For example, in a German case, X, an individual resident of Germany owned: (i) 90 per cent of the shares of US-Co, a company resident of the US (the remaining 10 per cent was owned by X's three children, who were residents of the US); and (ii) a 99 per cent interest of US-Pr, a US limited partnership. US-Co, in turn, was a 1 per cent

90 France, Conseil d'État (Supreme Administrative Court), 191191, 13 October 1999, legifrance.gouv.fr/ affichJuriAdmin.do?idTexte=CETATEXT000008076853\&dateTexte $=$. 
unlimited partner of US-Pr. The issue was whether US-Pr was entitled to the Germany-US treaty benefits. The Court held that this depended on whether or not US-Pr was a resident of the US within the meaning of the residence article of the treaty and noted that US-Pr was not a resident of the US in its own right, because partnerships were not taxed as such in the US and were not treated as corporate entities in the US. The Court however relied on the tax-transparent entity test of the residence article of the treaty (according to which a partnership is a resident of the US only to the extent that the partners are subject to US tax on the income as US residents) to conclude that such a test was not met with respect to his 99 per cent interest in US-Pr because X was not a resident of the US. The Court also held that in respect of the 1 per cent interest in US-Pr by US-Co, that requirement was not met since the income allocated to US-Co was not subject to US tax. ${ }^{91}$ The Court assumed that since the US-Co received and immediately paid the royalties to Neth-Co, it did not have any control over the income.

1.117 National Courts look at the contextual legal arrangements. For example, in a Spanish case several foreign companies for the management of copyrights and author's rights claimed a reduction of withholding tax on royalties under the royalty article of a number of treaties entered into by Spain and the Court held that those foreign companies were intermediaries or agents acting in the name of the holders of the right, i.e. the authors, and, since they acted on their behalf, could not be considered beneficial owners unless they proved that the authors in the name of whom they acted were residents of their same State. ${ }^{92}$

1.118 In other cases Courts have respected the legal form of the sale transactions. For example, in Mil Investments an individual X, resident of Belize (later Monaco), acquired shares of a Canadian public company (Co1), which were then transferred to a newly incorporated Cayman Islands company ( $\mathrm{NewCo}$ ) wholly owned by X. Co1 discovered natural resources in Canada, and its share increased substantially. NewCo exchanged its shares in Co1 for shares of another Canadian publicly traded company (Co2), leaving NewCo with less than 10 per cent of Co1. NewCo subsequently incorporated in Luxembourg and became a resident of Luxembourg for tax purposes. NewCo sold some of the $\mathrm{Co} 2$ shares realizing a gains that was exempt from tax in Canada under the capital gains article of the Canada-Luxembourg treaty. NewCo was also not taxed in Luxembourg as the adjusted cost base of the shares exceeded the proceeds of disposition. Eventually NewCo declared dividends equal to the

91 Germany, Finanzgericht Nordrhein-Westfalen (Tax court Nordrhein-Westfalen), 2 K 7574/96, 28 December 1998, Entscheidungen der Finanzgerichte, 1999, 320.

92 Spain, Tribunal Económico Administrativo Central (Central Economic-Administrative Court), RG 6294/ 1996, 22 September 2000, serviciosweb.meh.es/apps/doctrinateac/detalle.asp?button1=00/6294/1996. 
value of its interest in Co1, to be paid by way of the issue of two interestbearing promissory notes and $\mathrm{Co} 2$ purchased all the shares of $\mathrm{Co} 1$, including the 10 per cent held by NewCo. NewCo received proceeds of the disposition for its Co1 shares and claimed an exemption from Canadian tax under the capital gains article. The Court held that the tax benefit obtained was not an abuse of the treaty, and therefore the gains were not taxable in Canada because the requirements to exempt non-residents from taxation in Canada on the gains from the disposition of treaty property were met. ${ }^{93}$

\section{d. Beneficial owner of capital gains}

The 'beneficial owner' concept has been extended from typical cases involving interest or dividends to transactions concerning the sale of shares. In these situations the problem addressed by case law is whether an intermediate entity selling the shares (for example a holding company or a trust) of companies is in fact the beneficial owner of capital gains. A good example of a judicial look-through approach to identify the beneficial owner of capital gains is found in an Australian case, Resource, in which the acquisition structure relied on a chain of partnerships: PR1, a limited partnership formed in the Cayman Islands, bought shares in Co1, an Australian company that conducted mining activities in Australia, and subsequently sold some of its shares in Co1 and realized a gain. PR1 had one general partner (another partnership formed in the Cayman Islands) and several limited partners, most of which were US residents. PR1's affairs were managed by a Delaware LLC. Neither PR1 nor its manager nor any of the partners were residents of Australia. Australia did not have a treaty with the Cayman Islands, but had a treaty with the US (according to which a partnership is a treaty US resident if it is resident of the US for the purposes of tax, provided that its income is subject to US tax as income of a resident, either in the hands of the partnership or in the hands of its partners).

The question was: who realized the gain for the purposes of the Australia-US treaty? PR1 submitted that PR1 was a foreign partnership and a flow-through entity under the US domestic laws and it was not a US tax resident because the residence requirement in the treaty had not met. Thus, according to PR1, the gain was realized by the limited partners in PR1. The position of the tax authorities in Australia was instead that domestic provisions prevailed over the treaty and thus PR1 was the taxpayer making the gain. The Court accepted the position of PR1 and ruled that since PR1 was not a US treaty resident, the capital gains article of the treaty did not authorize Australia to tax the gains of

93 Canada, Tax Court of Canada, Mil Investments S.A. v. Her Majesty the Queen, 18 August 2006, [2006] 5 C.T.C. 2252. 
PR1. The Court also held that the limited partners of PR1 were the beneficial owners of the gain because the treaty provisions prevailed over the domestic provisions (i.e. PR1 was the recipient of the gain)..${ }^{94}$

1.121 In most cases Courts however have respected the legal form of the sale transactions. For example, in Sommerer, X emigrated from Austria to Canada, where he became a tax resident. $\mathrm{X}$ held shares in two Austrian companies, which he sold to an Austrian foundation, founded by the father of $\mathrm{X}$ for the benefit of his family, at fair market value. The foundation sold the shares to unrelated buyers, making a capital gain. Canadian tax authorities attributed the capital gain made by the foundation to $\mathrm{X}$ relying on domestic Canadian laws, which, if certain conditions are met, attribute to the settler of a trust the taxable capital gains realized by the trust, so long as he is a resident of Canada. The Court held that even though a trust existed between the parties, the sale by $\mathrm{X}$ of the shares was not in the nature of contribution as a settler and therefore the capital gain on the shares realized by the foundation could not be attributed to $\mathrm{X}$. The Court added that even if under domestic laws the gains were attributable to $X$, the capital gain on shares clause of the treaty would not allow Australia to tax the capital gains. ${ }^{95}$

1.122 A SC may retain its power to tax gains from sales of shares by non-resident persons by relying on domestic anti-abuse rules even if no mention of them (except for PE-related transactions) is made in the Commentary. For example, in a South Korean case the Court held that in a private equity transaction in which two UK investment funds had invested in a Korean company through two Luxembourg and two Belgium companies, which eventually sold shares in the Korean company that owned immovable property generated capital gains taxable in Korea, the decision was reached on the basis of domestic substanceover-form doctrine in spite of the treaty rule attributing exclusive taxation to the countries of the seller of shares.

1.123 The Court observed that the Belgian companies were not established by the taxpayers for substantial business purposes but for the purpose of enjoying the treaty benefits of the capital gains article of the Belgian treaty which prevented Korea from taxing the capital gains from the sale of the shares in the Korean immovable property company. The indicators of the abusive conduct were that the two UK investment funds played a leading role in the whole process of acquisition and funded the price paid in consideration for the shares the

94 Australia, Federal Court of Australia, Resource Capital Fund III LP v. Commissioner of Taxation, 26 April 2013, [2013] FCA 363.

95 Canada, Federal Court of Appeal, Peter Sommerer v. Revenue Agency, 13 July 2012, 2012 FCA 207. 
Belgian companies who were not engaged in economic activities in Belgium, nor had independent economic interests in the real property investment. ${ }^{96}$

\section{e. Beneficial owner of income of an entertainer/sportsperson}

Art. $17 \S 2$ provides that if income in respect of personal activities exercised by

an entertainer/sportsperson in his capacity as such accrues not to the entertainer/sportsperson himself but to another person, then that income may, notwithstanding Artt. 7 and 15, be taxed in the SC (the CS in which the activities of the entertainer/sportsperson are exercised). Art. $17 \S 2$ is a special kind of beneficial owner rule, but differs from that rule. The rationale of the beneficial ownership principle is to prevent residents of third countries having access to the treaty benefits by ensuring that the recipient of income (dividends, interest or royalties) is also the beneficial owner of that income. By contrast the rationale of Art. $17 \S 2$ is to prevent entertainers and sportspersons obtaining an inappropriate exemption by transforming their remuneration into business profits of a third party (not subject to tax in the SC). National Courts have developed judicial approaches that essentially obtain the same result when the entertainer's look-through clause is not present in the applicable treaty, and also domestic anti-avoidance rules operate in that direction. For details on Art. $17 \S 2$ see infra at paras 9.50-9.77.

\section{TAXES COVERED BY THE TREATIES (ART. 2)}

\section{A. Scope: taxes on income and on capital (Art. 2 § 1)}

Art. 2 ensures the identification of the CSs' taxes covered by treaty to avoid the necessity of concluding a new treaty whenever the CSs' domestic laws are modified, and also ensures that the CS reciprocally notify significant changes in their domestic laws. ${ }^{97}$ The structure of Art. 2 is the following: provisions that define the objective scope of the Convention as covering taxes on income and on capital $(\S 1)$; the definition of taxes on income and on capital $(\S 2)$; a list of those taxes $(\S 3)$, and a clause about new taxes $(\S 4)$.

The scope of the Convention is defined by Art. $2 \S 1$ which provides that it shall apply to taxes on income and on capital imposed on behalf of a CS or of its political subdivisions or local authorities, irrespective of the manner in which they are levied. The Commentary observes that what matters in identifying the covered taxes is how they are levied, while it is immaterial on

96 South Korea, Supreme Court, 2010 du 11948, 26 April 2012, (2012) 15 ITLR 1.

97 Commentary to Art. 2 § $1-2$. 
behalf of which authorities such taxes are imposed. A distinction should be made, however, when one of the CS is a federal system, as State and local taxes are often excluded. For example, a US case addressed whether the New York State and City taxes paid by a US branch of a company resident of Finland were deductible from income taxable in Finland. The Court held that those taxes were not deductible because they did not constitute business expenses taxes and were not be creditable because they did not fall under the covered taxes article. ${ }^{98}$

\section{B. Definition of taxes on income and on capital (Art. $2 \S 2$ )}

1.127 Art. $2 \S 2$ provides that there shall be regarded as taxes on income and on capital all taxes imposed on total income, on total capital, or on elements of income or capital, including taxes on gains from the alienation of movable property/immovable property, taxes on the total amounts of wages/salaries paid by enterprises, as well as taxes on capital appreciation. So Art. 2 § 1 includes duties or charges accessory to taxes (increases, costs, interest, etc.), but does not include social security charges, or any other charges if there is a direct connection between the levy and individual benefits. ${ }^{99}$ For example, in a case decided in New Zealand an individual resident there earned employment income in the US and in New Zealand and claimed a credit for social security tax paid in the US. The Court refused to allow the credit because US social security taxes were excluded by the covered taxes article. ${ }^{100}$

\section{Income taxes}

1.128 The core of judicial decisions concerning Art. 2 consists of the analysis of whether domestic taxes fall either in the category of income tax or in that of capital taxes which are covered by the treaties. So, if extraordinary taxes and local taxes in federal systems are not considered, in most case domestic taxes (such as municipal business taxes on payroll, net wealth taxes, forfeit taxes, taxes on lottery prizes) are deemed by courts to fall under the treaties.

1.129 Several cases in Austria have focused on municipal business taxes on payroll. For example, a company resident of Japan had a PE in Austria which paid a municipal tax (Kommunalsteuer) in Austria, a substitute for the abolished business tax on payroll (Gewerbesteuer), levied on the aggregate salaries paid to

98 Finland, Korkein Hallinto-oikeus (Supreme Administrative Court), 2004:12, 6 February 2004, finlex.fi/fi/ oikeus/kho/vuosikirjat/2004/200400226.

99 Commentary to Art. 2 § $3-4$.

100 New Zealand, Court/Chamber Taxation, Not disclosed at Taxation Review Authority v. Commissioner of Inland Revenue, 18 January 1990, (1990) 12 NZTC 2,134. 
and deductible from corporate income tax. The Court held that the municipal tax fell under the covered taxes article so that the exemption previously available for the business tax on payroll was also available for the municipal tax. The Court observed that denying the exemption would have amounted to an undue unilateral modification of the treaty referring to Art. $31 \S 1$ of the Vienna Convention on the Law of Treaties. ${ }^{101}$ In a case concerning the same municipal tax the Court reached the same conclusion reasoning that the new municipal tax on the aggregate salaries was ancillary to the replaced tax. ${ }^{102}$

In another French case an individual resident of Austria owned holdings in a 1.130 French company. On the basis of French law non-residents were subject to the French net wealth tax only on assets situated in France, but 'passive financial investments' (i.e. placements financiers such as non-qualified participations) were exempt from the tax, while individuals resident of France were subject to the net wealth tax with respect to their property situated inside or outside France. The issue was whether the treaty applied to the French net wealth tax on non-residents in light of the fact that such a tax was not expressly mentioned in the covered taxes article.

The Court determined that the French net wealth tax was similar to the Austrian net wealth tax imposed on an individual resident of Austria and observed that the aim of the treaty was to avoid double taxation not only in respect of existing taxes but also in respect of future similar or identical taxes. The Court held that an individual resident of Austria could not be subject to the net wealth tax in France with respect to his participation in a French company because the applicable treaty allocation rule provided that capital was taxable only in the country of residence of the person who owned it. ${ }^{103}$

A similar conclusion was reached in the Netherlands in respect to 'forfeit taxation' of income from savings and investments levied in the Netherlands. The Court held that such forfeit taxation was an income tax for three reasons: it was integrated with the taxation of income from other sources; it allowed the deduction of personal allowances not deductible from other items of income;

101 Austria, Verwaltungsgerichtshof (Supreme Administrative Court), 2000/13/0134, 28 March 2001, ris.bka. gv.at/JudikaturEntscheidung.wxe?Abfrage=Vwgh\&Dokumentnummer=JWR_2000130134_20010328X01.

102 Austria, Verwaltungsgerichtshof (Supreme Administrative Court), 99/15/0265, 3 August 2000, ris.bka.gv.at/ JudikaturEntscheidung.wxe?Abfrage=Vwgh\&Dokumentnummer=JWR_1999150265_20000803X01.

103 France, Tribunal de Grande Instance Paris (Grand Instance Court Paris), 1985-01-17, 17 January 1985, Revue de Jurisprudence Fiscale 1985, 3, 267. 
and the income from savings and investments was taken into account for determining the amount of the deductible extraordinary expenses. ${ }^{104}$

1.133 Lottery prizes are also covered by the treaties if included in the income tax. A Swiss resident won a lottery prize in Germany, which was taxed in Germany and in Switzerland, and argued that Switzerland could not tax the lottery prize because the covered taxes article explicitly excluded the application of the treaty to lottery winnings. The Court observed that charges on lottery prizes constituted an 'income tax' or 'capital appreciation tax' within the meaning of the covered taxes article so that the treaty was applicable to them, but also determined that the covered taxes article was not relevant to the case at hand and did not prevent Switzerland from taxing the lottery prize which, according to domestic laws, was taxed at the place of residence of the taxpayer. The Court ruled that the covered taxes article only excluded the application of the treaty with respect to tax levied in the SC on lottery prizes but not its application to lottery prizes in general in the RC. ${ }^{105}$ In certain cases extraordinary taxes are deemed to be covered by treaties in so far as they have, in substance, the structure of an income tax, for example, the so-called 'windfall tax' in the UK is characterized as an excess profit tax. ${ }^{106}$

1.134 Local business taxes tend to be excluded when they do not constitute a local layer of the national income taxes. For example, the German local business tax was excluded from the coverage of the treaties because of its peculiar structure.

1.135 In a French case, an Italian airline company exercised its activity in France through a branch, where, under French domestic laws, it was liable to corporate income tax. The issue was whether this also included a so-called apprentice tax provided for by French domestic laws. The Court held that the treaty, which provides for a corporate income tax exemption to aircraft companies, did not cover apprentice tax. ${ }^{107}$

1.136 A local business tax that faced some hurdles was the Italian tax on local income levied with a separate additional rate on all types of income with the exclusion of dependent personal services income. Initially this local tax was considered

104 The Netherlands, Hoge Raad der Nederlanden (Supreme Court), 42.211, 1 December 2006, Beslissingen in Belastingzaken, 2007, 68.

105 Switzerland, Verwaltungsgericht Bern (Administrative Court Bern), 1996-08-30, 30 August 1996, Steuerentscheid, 1997, A 31.1, 5.

106 United States, US Supreme Court, PPL Corporation and Subsidiaries v. the Commissioner of Internal Revenue, 20 May 2013, 2013-1 USTC (CCH) 50335.

107 France, Conseil d'État (Supreme Administrative Court), 249801, 15 July 2004, Revue de jurisprudence fiscale, 11/2004, 1089. On a similar fact situation, a Russian decision: Russia, Commercial Court for Moscow Circuit (Supreme Commercial Court), A40-1164/11-99-7, 20 February 2012, FNS Letter \# GD-4-3/4566. 
to be covered by the treaties in so far as it was a tax administered by the central government, in spite of its denomination as local. In a subsequent case involving the US, the Court held that the covered taxes article did not include the local tax because the amended treaty did not cover such a tax and the notes exchanged did not mention it. ${ }^{108}$

Extraordinary taxes also tend to be excluded from the coverage of the treaties in so far as they pursue regulatory or policy goals, like for example the Greek extraordinary social responsibility contribution. ${ }^{109}$

\section{Taxes on profits and gains derived from the alienation of property}

Taxes on the gains derived from the alienation of movable or immovable property are generally covered by the capital gains article, but it is left to domestic laws to decide whether to levy a special tax on capital gains or treat them as ordinary income. ${ }^{110}$ As a result the issue arose in case law whether treaties apply to capital gains when domestic laws do not specify whether capital gains are treated separately or as ordinary income. For example, in the Virgin case the issue was whether the treaties Australia had concluded with the Netherlands and the UK covered a tax on a capital gains imposed in Australia (CGT) on the disposal of shares in Australian companies. The Court held that the 'Australian income tax' referred to in the covered taxes article included the CGT, which constituted a part of the Australian income tax rather than a separate tax..$^{111}$ The subsequent Undershaft case addressing the same issue followed the decision in Virgin also in light of the fact that Australian tax authorities issued a position accepting that judgment. ${ }^{112}$

\section{Extraordinary taxes}

The Commentary clarifies that countries are free to clarify in their treaties whether 'extraordinary taxes' are covered. What happens is generally that only ordinary taxes are covered by the treaty, while extraordinary taxes are excluded as a result of judicial qualifications in so far as they pursue regulatory or policy goals. For example, in 2010, faced by a severe financial crisis, Greece introduced an extraordinary social responsibility contribution imposed on the total net

108 Italy, Corte Suprema di Cassazione (Supreme Court), 18957, 20 November 2003, leggiditalia,it. Contra Italy, Corte Suprema di Cassazione (Supreme Court), 1122, 2 February 2000, leggiditalia.it.

109 Greece, Administrative Court of Appeals of Athens, 481/2012, 7 February 2012, European Tort Law Yearbook, 3, 1, 273.

110 Commentary to Art. $13 \S 4$.

111 Australia, Federal Court of Australia - Full Court, Virgin Holdings SA v. Federal Commissioner of Taxation, 10 October 2008, [2008] FCA 1503.

112 Australia, Federal Court of Australia, Undershaft Ltd v. Commissioner of Taxation, 3 February 2009, [2009] FCA 41. 
profits of corporate taxpayers who had reported total net profits of over EUR 100,000 in 2009 and included an exemption for corporate taxpayers with total net profits below that amount. The contribution was calculated in the same way and followed the same rules as the corporate income tax.

1.140 The issue was whether a US corporate taxpayer was subject to the extraordinary contribution. The Court held that the contribution was not included in the taxes covered by the Greece-US treaty because it was an extraordinary fiscal burden imposed on the high-income earners, did not constitute an increase of the ordinary corporate income tax, and did not depend on the ability to pay the corporate income tax. As a result the US taxpayer was not granted treaty protection. ${ }^{113}$

1.141 By contrast in PPL Corporation, the US Supreme Court admitted treaty coverage to a UK tax which in fact had regulatory purposes. A US corporation owned a UK government-owned utility company which was privatized together with other companies and subsequently subjected to the "windfall tax', a charge enacted to compensate for the low price of the flotation in light of the profit potential of the privatized companies (the 'windfall'). The windfall tax was a one-time 23 per cent tax on the amount of the windfall defined as the excess of the 'profit-making value' (calculated by multiplying the company's average annual profit during its initial period by nine, the assumed price-to-earnings ratio) of each privatized company over its 'flotation value' (i.e. the total sales price that investors paid for the company when the UK government sold it).

1.142 The issue was whether the FTC should be allowed in the US for the windfall tax in so far as it constituted an 'income tax' for the purposes of the treaty and IRC section 901. The Court determined that the windfall tax was an excess profits tax, which is a category of income tax in the US sense, because it constituted a tax on net income disguised as a tax on the difference between the 'profit-making value' and the 'flotation value'. The Court observed that the substantive effect of the windfall tax formula was to impose a 51.71 per cent tax on all profits earned above a threshold by the utility companies that were privatized and this proved that such a tax was in effect an excess profits tax. ${ }^{114}$

113 Greece, Administrative Court of Appeals of Athens, 481/2012, 7 February 2012, European Tort Law Yearbook, 3, 1, 273.

114 United States, US Supreme Court, PPL Corporation and Subsidiaries v. the Commissioner of Internal Revenue, 20 May 2013, 2013-1 USTC (CCH) 50335. 
In Entergy the Court confirmed that the UK windfall was a creditable foreign tax relying on PPL Corporation. ${ }^{115}$

\section{Taxes on capital}

Straightforward taxes on capital are generally included in the covered taxes article or in the capital taxes article (see infra at paras 5.75-5.93). In certain cases it is relatively easy to exclude the capital nature of a tax. For example, X, an individual resident of Switzerland, owned immovable property situated in the Netherlands that he temporarily occupied as an abode. He was charged a 'commuter tax' by the Netherlands municipality concerned based on the fair market value of the abode not being his main residence. $\mathrm{X}$ claimed that the commuter tax was a tax on capital charged in violation of the SwitzerlandNetherlands treaty, but the Court determined that the tax was not a capital tax covered by the treaty because it was not based on ownership of the property.

In other situations the capital tax characterization is not linear. For example, collective investment vehicles operating in Belgium were subject to an annual tax on collective investment (CivTax). The CivTax when introduced in 1993 only applied to Belgian CIVs but in 2003 it was extended to foreign CIVs operating in Belgium. The taxable basis for the CivTax was the net asset value of the outstanding shares/units in Belgium. The Court held that this was a 'tax on capital' because the covered taxes article defined 'taxes on capital' as 'all taxes imposed on total capital, or on elements of capital' and CivTax was a tax on elements of capital.

\section{List of covered taxes (Art. $2 \S 3$ )}

Art. $2 \S 3$ simply lists the taxes in force at the time of signature ${ }^{116}$ of the treaty. The general approach, however, is that such a list is not exhaustive. For example, in the Belgian case concerning the CivTax, the Court rejected the argument of tax authorities that the treaty did not apply to the CivTax because it was not listed in the covered taxes article: the CivTax simply extended to foreign CIVs in 2003 so there was no reason to include a reference to it in the covered taxes article. The Court also observed that the enumeration of taxes and the duty to inform the other CS of new taxes in the covered taxes article restricts the scope of the treaty. Instead, the purpose of Art. $3 \S 2$ is to ensure

115 United States, US Tax Court, Entergy Corporation \& Affiliated Subsidiaries v. Commissioner of Internal Revenue, 9 September 2010, T. C. Memo. 2010-197.

116 Commentary to Art. $2 \S 5$. 
that the treaty be interpreted in good faith in accordance with Art. 31 of the Vienna Convention on the Law of Treaties. ${ }^{117}$

\section{New taxes (Art. 2 §4)}

1.146 Art. $4 \S 4$ provides that the Convention shall also apply to any identical or substantially similar taxes that are imposed after the date of signature of the Convention in addition to, or in place of, the existing taxes and that the Competent Authorities of the CSs shall notify each other of any significant changes that have been made in their taxation laws. ${ }^{118}$ This criterion of 'substantially similar taxes' has been used flexibly by national Courts, so that the objective purpose of treaties is open-ended and geared to domestic changes, without needing to negotiate new treaties.

1.147 For example, in Austria a municipal tax on aggregate salaries paid was introduced to replace the business tax on payroll. The Court held that the new municipal tax was an 'identical or similar tax' within the meaning of the covered taxes article, because the subject matter of the replaced and replacing tax was the same. More specifically the new tax was 'similar' because its personal scope was broader but not functionally different to the scope of the old tax. The Court held that the new municipal tax (like the old business tax on payroll) was levied as part of the tax on industrial and commercial enterprises in both Austria and Germany and therefore the exemption granted to a German taxpayer was not contrary to Art. 31 of the Vienna Convention on the Law of Treaties because it served the object and purpose of the treaty, namely the avoidance of double taxation. ${ }^{119}$

1.148 In another case concerning the same tax the Court reached the same conclusion that the new tax was similar to the old tax reasoning that both the old and the new tax were taxes on industrial and commercial business. ${ }^{120}$ In a similar case decided in Spain, a company resident of Luxembourg, was subject to a withholding tax on interest at source and claimed that such a withholding tax was creditable against the Luxembourg municipal business tax. The Court accepted the claim arguing that the business tax was similar to the municipal trade tax on profits and capital that existed at the date of signature of the

117 Belgium, Tribunal de Première Instance Bruxelles (Court of First Instance Bruxelles), 2006/2662/A, 2 August 2011, TFR, 2012, liv. 430, 935.

118 Commentary to Art. 2 § 7-8.

119 Austria, Verwaltungsgerichtshof (Supreme Administrative Court), 99/15/0265, 3 August 2000, ris.bka.gv.at/ JudikaturEntscheidung.wxe?Abfrage=Vwgh\&Dokumentnummer=JWR_1999150265_20000803X01.

120 Austria, Verwaltungsgerichtshof (Supreme Administrative Court), 98/13/0021, 15 December 1999, ris.bka. gv.at/JudikaturEntscheidung.wxe?Abfrage=Vwgh\&Dokumentnummer=JWR_1998130021_19991215X01. 
treaty. ${ }^{121}$ In the case concerning the 'forfeit taxation' in the Netherlands discussed supra at para 1.132 the issue was whether such taxation of income from savings and investments levied in the Netherlands was a net wealth tax. The Court held that such forfeit taxation was included in the covered taxes article because it was similar to the repealed taxes. ${ }^{122}$

In certain cases the new taxes are deemed to be 'identical' to the old ones: for example, in Virgin discussed supra at para 1.138, the Court noted that the CGT was 'substantially similar, if not identical, to the income tax'. ${ }^{123}$ In a French case a company resident of Canada sold immovable property in France. Tax authorities imposed an advance levy, which was introduced after the conclusion of the applicable treaty on non-resident individuals or companies that did not have an establishment in France. The Court held that the levy constituted a tax which was identical to the taxes mentioned in the covered taxes article. ${ }^{124}$ By contrast, in the Greek case concerning the extraordinary social responsibility contribution ${ }^{125}$ and in the Danish tax on termination of a private pension ${ }^{126}$ the Court found that the new taxes were not 'substantially similar' to existing ordinary taxes because of their extraordinary nature.

\section{BIBLIOGRAPHY}

Aage Skaar, Arvid, 'The Continental Shelf and Tax Treaty - A Case Study' (1993) 38 Brit. Tax Rev. 189.

Arginelli, Paolo, et al, 'The Royal Bank of Scotland case: More controversy on the interpretation of the term "beneficial owner" in: Raffaele Russo and Renata Fontana (eds), A Decade of Case Law. Essays in honour of the 10th anniversary of the Leiden Adv LLM in International Tax Law (IBFD 2008).

Austry, Stéphane, et al, 'Les Clauses de Bénéficiaire Effectif Ont-Elles un Effet Utile?' (2008) 12 Revue de Jurispr. Fisc. 1087.

Avella, Francesco, 'Recent Tax Jurisprudence on the Concept of Beneficial Ownership for Tax Treaty Purposes' (2015) 55 Eur. Tax. 56.

Avery Jones, John F., 'The Beneficial Ownership Concept Was Never Necessary in the Model' in: Michael Lang et al. (eds), Beneficial Ownership: Recent Trends (IBFD 2013).

121 Luxembourg, Tribunal Administratif (Administrative Tribunal) 18793/19298, 11 July 2005, webcache.googleusercontent.com/search?q=cache:kIhiRGMD0NMJ:www.ja.etat.lu/18793.doc+\&cd=1\&hl $=$ it\&ct $=$ clnk\&gl=it.

122 The Netherlands, Hoge Raad der Nederlanden (Supreme Court), 42.211, 1 December 2006, Beslissingen in Belastingzaken, 2007, 68.

123 Australia, Federal Court of Australia - Full Court, Virgin Holdings SA v. Federal Commissioner of Taxation, 10 October 2008, [2008] FCA 1503.

124 France, Conseil d'État (Supreme Administrative Court), 93187, 26 November 1975, Droit fiscal, 1976, 733.

125 Greece, Administrative Court of Appeals of Athens, 481/2012, 7 February 2012, European Tort Law Yearbook, 3, 1, 273.

126 Denmark, Østre Landsret (High Court of Eastern Denmark), 300/1989, 5 May 1992, Tidsskrift for Skatteret, 1992, 291. 
Avery Jones, John F., et al., 'Characterization of other States' Partnerships for Income Tax' (2002) 56 Bull. Intl. Fisc. Doc. 288.

Avery Jones, John F., et al., 'OECD Discussion Draft Clarification of the Meaning of "Beneficial Owner" in the OECD Model Tax Convention', 15 July 2011, http:// www.oecd.org/tax/treaties/48420432.pdf (accessed 28 November 2015).

Avi-Yonah, Reuven, and Christiana H. Panayi, 'Rethinking Treaty Shopping: Lessons for the European Union' in: Michael Lang et al. (eds), Tax Treaties: Building Bridges between Law and Economics (IBFD 2010).

Baker, Philip, 'Beneficial Ownership: after Indofood' (2007) 4 Gray's Inn Tax Chamber Rev. 123.

Baker, Philip, 'United Kingdom: Indofood International Finance Ltd v. JP Morgan Chase Bank $N A$ ' in: Michael Lang et al. (eds), Beneficial Ownership: Recent Trends (IBFD 2013).

Bates, John, et al., 'Limitation on Benefits Articles in Income Tax Treaties: The Current State of Play' (2013) 41 Intertax 395.

Baumgartner, Bobath, Das Konzept des Beneficial Owner im Internationalen Steuerrecht der Schweiz (Schultess 2010).

Blanluet, Gauthier, 'La Notion de Bénéficiaire Effectif en Droit Fiscal International' in: Martial Chadefaux et al. (eds), Ecrits de fiscalité des entreprises: Etudes à la mémoire du professeur Maurice Cozian (Litec 2009).

Booker, Thomas, 'Beneficial Ownership' (2013) 53 Eur. Tax. 164.

Brandstetter, Patricia, Taxes Covered. A Study of Article 2 of the OECD Model Conventions (IBFD 2011).

Brauner, Yariv, 'Beneficial Ownership In and Outside US Tax Treaties' in: Michael Lang et al. (eds), Beneficial Ownership: Recent Trends (IBFD 2013).

Bundgaard, Jakob and Niels Winther-Sørensen, 'Beneficial Ownership in International Financing Structures' (2008) 50 Tax Notes Int. 587.

Burgstaller, Eva, 'Kommunalsteuer und DBA' (2004) Steuer und Wirtschaft International 17.

Chew, Victor, 'The Application of Tax Treaties to Collective Investment Vehicles: Beneficial Owner Requirement Explained?' (2015) 17 Derivatives \& Financial Instruments 6.

Collier, Richard, 'Clarity, Opacity and Beneficial Ownership' (2011) 56 Brit. Tax Rev. 6684.

Committee of Experts on International Cooperation in Tax Matters, Concept of Beneficial Ownership: Discussion of Key Issues and Proposal for Changes to the UN Model Commentary E/C.18/2010/CRP.9, 12 October 2010, http://www.un.org/esa/ffd/wp-content/uploads/ 2014/10/6STM_BeneficialOwnership.pdf (accessed 22 November 2015).

Da Silva, Bruno, 'Granting Tax Treaty Benefits to Collective Investment Vehicles: a Review of the OECD Report and the 2010 Amendments to the Model Tax Convention' (2011) 39 Intertax 195.

Dagnese, Napoleão, 'Is Brazil 'Developed'? Termination of the Brazil-Germany Tax Treaty' (2006) 34 Intertax 195.

de Broe, Luc, International Tax Planning and Prevention of Abuse (IBFD 2008).

Duff, David G., 'Beneficial Ownership: Recent trends' in: Michael Lang et al. (eds), Beneficial Ownership: Recent Trends (IBFD 2013).

Duff, David G.,'Responses to Treaty Shopping: A Comparative Evaluation' in: Michael Lang et al. (eds), Tax Treaties: Building Bridges between Law and Economics (IBFD 2010).

Furlan, Alessandro and Michele Toccaceli, 'Il Concetto di 'Beneficial Owner' nei Trattati Internazionali Contro le Doppie Imposizioni e nelle Direttive Comunitarie' (2009) Fiscalità Internazionale 5390.

Gouthiere, Bruno, L'application des Conventions Fiscales Aux Societies de Personnes (Francis Lefebvre 2000).

Guttman, Daniel, 'Beneficial Ownership as Anti-Abuse Provision: The Bank of Scotland Case' in: Michael Lang et al. (eds), Beneficial Ownership: Recent Trends (IBFD 2013).

Hattingh, Johann P., 'Article 1 of the OECD Model: Historical Background and the Issues Surrounding It' (2003) 57 Bull. Intl. Fisc. Doc. 215. 
Hattingh, Johann P., 'The Role and Function of Article 1 of the OECD Model' (2003) 57 Bull. Intl. Fisc. Doc. 546.

Hofstatter, Mathias, and Patrick Plansky, Dual Residence in Tax Treaty Law and EC Law (Linde 2009).

Jain, Saurabh, Effectiveness of the Beneficial Ownership Test in Conduit Company Cases (IBFD 2013).

Kasaizi, Abeid, 'Interpretation of the Material Scope of Taxes Covered by the OECD-MC (Art. 2 OECD-MC)' in: Michael Schilcher and Patrick Weninger (eds), Fundamental Issues and Practical Problems in Tax Treaty Interpretation (Linde 2008).

Krever, Richard, and Jason Chang, 'Is Hong Kong Part of China for Tax Treaty Purposes', (2002) 2 Tax Specialist 62.

Lang, Michael, 'Kommunalsteuer und DBA', (2005) 15 Steuer und Wirtschaft International 16.

Lang, Michael, 'Taxation of Income in the Hands of Different Taxpayers from the Viewpoint of Tax Treaty Law', (2001) 55 Bull. Intl. Tax. 596.

Lang, Michael, "Taxes Covered - What is a "Tax" According to Article 2 of the OECD Model?’, (2005) 59 Bull. Intl. Fisc. Doc. 216.

Lang, Michael et al., Beneficial Ownership: Recent Trends (IBFD 2013).

Lang, Michael, The Application of the OECD Model Tax Convention to Partnerships - A Critical Analysis of the Report Prepared by the OECD Committee on Fiscal Affairs (Kluwer Law International 2000).

Lenger, Barbara, 'Subject-to-Tax Provisions and The Taxation of Employment Income in DTC Law' in: Daniela Hohenwarter and Vanessa Metzler (eds), Taxation of Employment Income in International Tax Law (Linde 2009).

Luthi, Christian, 'Switzerland's Treaty Policy' (1996) 50 Bull. Intl. Fisc. Doc. 336.

Martín Jiménez, Adolfo, 'Beneficial Ownership as an Attribution-of-Income Rule in Source and Residence Country Perspectives' in: Michael Lang et al. (eds), Beneficial Ownership: Recent Trends (IBFD 2013).

Martín Jiménez, Adolfo, 'Beneficial Ownership: Current Trends' (2010) 2 World Tax J. 135.

Martín Jiménez, Adolfo, 'Defining the Objective Scope of Income Tax Treaties: The Impact of Other Treaties and EC Law on the Concept of Tax in the OECD Model' (2005) 59 Bull. Intl. Fisc. Doc. 10.

Menétrey, Gérard, 'Les Privileges Fiscaux des Fonctionnaires Internationaux' (1973) Revue de Droit Fiscal 225.

Menétrey, Gérard, 'Le Statut des Representations Diplomatiques et Consulaire et de Leur Personnel' (1978) 1 Revue de Droit Fiscal 1.

Mignon, Emmanuelle, 'Fiscalité Internationale de Sociétés de Personnes; la Transparence N'Est Pas le Vide (1999) 12 Revue de Jurispr. Fisc. 931.

Murray, Paul, 'OECD Partnership Report: Reshaping Treaty Interpretation?' (2000) 45 Brit. Tax Rev. 71.

OECD-TAG, Discussion Draft on the Application of the Tax Treaties to State-owned Entities, Including Sovereign Wealth Funds (OECD-TAG 2009).

OECD-TAG, Double Taxation Conventions and the Use of Conduit Companies (OECD-TAG 1986).

OECD-TAG, International Tax Avoidance and Evasion - Four Related Studies (OECD-TAG 1987).

OECD-TAG, Tax Treaty Issues Related to REITs (OECD-TAG 2007).

OECD: The Granting of Treaty Benefits with Respect to the Income of CIV (OECD-TAG 2010).

Oliver, David and Ross Fraser, 'Beneficial Ownership: HMRC's Draft Guidance on Interpretation of the Indofood Decision' (2007) 52 Brit. Tax Rev. 139.

Oliver, David and Ross Fraser, 'Treaty Shopping and Beneficial Ownership: Indofood International Finance Ltd v JP Morgan Chase Bank NA London branch' (2006) 51 Brit. Tax Rev. 4 422. 
Oliver, David B, 'Some Aspects of the Territorial Scope of Double Tax Treaties' (1990) 35 Brit. Tax Rev. 9303.

Oliver, David et al. 'Beneficial Ownership and the OECD Model' (2001) 46 Brit. Tax Rev. 127.

Parolini, Andrea, 'Del Commercial: Conduit Arrangements and Abuse of Tax Treaties', in: Raffaele Russo and Renata Fontana (eds), A Decade of Case Law. Essays in honour of the 10th Anniversary of the Leiden Adv LLM in International Tax Law (IBFD 2008).

Reimer, Ekkehart, 'How To Conceptualize Beneficial Ownership' in: Michael Lang et al. (eds), Beneficial Ownership: Recent Trends (IBFD 2013).

Rowland, Amanda, 'Beneficial Ownership in a Corporate Context: What is It? When is It Lost? Where does It Go?' (1997) 42 Brit. Tax Rev. 3186.

Shapiro, Daniel, 'OECD Tax Treaties: Who Beneficially Owns Dividends in a Total Return Swap?' (2009) 27 Taxation of Investment J. 1325.

Susanti, Niken, 'An Analysis of the Special Treaty Provisions Relating to Continental Self Activities', (2008) 48 Eur. Tax. 186.

Tenore, Mario, 'Taxes Covered: The OECD Model (2010) versus EU Directives' (2012) 66 Bull. Intl. Tax. 27.

Tolstrup, Bodil and Nikolaj Bjørnholm, 'Beneficial Ownership - Withholding Tax on Dividends and Interest from the Danish Perspective' (2011) 65 Bull. Intl. Tax. 503.

Vallada, Felipe, 'Beneficial Ownership under Articles 10, 11 and 12 of the 2014 OECD Model Convention', in: Michael Lang et al. (eds), The OECD-Model-Convention and Its Update 2014 (IBFD 2015).

Van den Ven, Mart, 'Diplomatic Tax Privileges, Past, Present and Future' (1988) 10 Intertax 306.

Vogel, Klaus, Tax Treaty News: Liable to Tax Under Article 4 of the OECD Model Convention (IBFD 2001).

Ward, David, 'Abuse of Tax Treaties' (1995) 23 Intertax 176.

Wheeler, Joanna, The Attribution of Income to a Person for Tax Treaty Purposes (IBFD 2005). 